\title{
Artemisinin mimics calorie restriction to extend yeast lifespan via a dual-phase mode: a conclusion drawn from global transcriptome profiling
}

\author{
WANG DaTing ${ }^{1}$, WU Ming ${ }^{2}$, LI SiMing ${ }^{3}$, GAO Qian ${ }^{1} \&$ ZENG QingPing ${ }^{1 *}$ \\ ${ }^{1}$ Tropical Medicine Institute, Guangzhou University of Chinese Medicine, Guangzhou 510405, China; \\ ${ }^{2}$ School of life Science, Sun Yat-sen University, Guangzhou 510275, China; \\ ${ }^{3}$ The Second Affiliated Hospital, Guangzhou University of Chinese Medicine, Guangzhou 510375, China
}

Received April 21, 2014; accepted June 17, 2014; published online February 9, 2015

\begin{abstract}
Calorie restriction (CR) promotes longevity among distinct organisms from yeast to mammals. Although CR-prolonged lifespan is believed to associate with enhanced respiratory activity, it is apparently controversial for accelerated energy consumption regardless of insufficient nutrient intake. In reconciling the contradiction of less food supply versus much metabolite dispense, we revealed a CR-based mode of dual-phase responses that encompass a phase of mitochondrial enhancement (ME) and a phase of post-mitochondrial enhancement (PME), which can be distinguished by the expression patterns and activity dynamics of mitochondrial signatures. ME is characterized by global antioxidative activation, and PME is denoted by systemic metabolic modulation. CR-mediated aging-delaying effects are replicated by artesunate, a semi-synthetic derivative of the antimalarial artemisinin that can alkylate heme-containing proteins, suggesting artesunate-heme conjugation functionally resembles nitric oxide-heme interaction. A correlation of artesunate-heme conjugation with cytochrome $c$ oxidase activation has been established from adduct formation and activity alteration. Exogenous hydrogen peroxide also mimics CR to trigger antioxidant responses, affect signaling cascades, and alter respiratory rhythms, implying hydrogen peroxide is engaged in lifespan extension. Conclusively, artesunate mimics CR-triggered nitric oxide and hydrogen peroxide to induce antioxidative networks for scavenging reactive oxygen species and mitigating oxidative stress, thereby directing metabolic conversion from anabolism to catabolism, maintaining essential metabolic functionality, and extending life expectancy in yeast.
\end{abstract}

calorie restriction, nitric oxide, artesunate, hydrogen peroxide, longevity, Saccharomyces cerevisiae

Citation: Wang DT, Wu M, Li SM, Gao Q, Zeng QP. Artemisinin mimics calorie restriction to extend yeast lifespan via a dual-phase mode: a conclusion drawn from global transcriptome profiling. Sci China Life Sci, 2015, 58: 451-465, doi: 10.1007/s11427-014-4736-9

Calorie restriction (CR), the limitation of food intake without malnutrition, is dedicated to adapt starvation among eukaryotes [1]. As an evolutionarily conserved character, CR-enhanced survival and longevity have been described in yeast [2], worms [3], fruit flies [4] and mammals [5]. In yeast, both the chronological lifespan (CLS) and the replicative lifespan (RLS) can be extended by reducing glucose from $2 \%$ to $0.5 \%$. CLS measures the length of time yeast

*Corresponding author (email: qpzeng@gzhtcm.edu.cn) cells remain viable at a non-dividing state (postmitotic survival), whereas RLS counts the number of cell divisions an individual yeast cell undergoes before senescence (division potential). While CLS is more relevant to the postmitotic cell aging, RLS is closely related to the replicative aging such as in stem cells [6].

In mammals, CR is believed to induce cyclic guanosine monophosphate (cGMP) for the activation of epithelial nitric oxide synthase (eNOS), which initiates mitochondrial biogenesis and prolongs lifespan via enhanced nitric oxide 
(NO) production [7-9]. As supporting evidence, the NO donor compound S-nitrosoglutathione indeed confers yeast lifespan extension [10]. However, no NOS homologs have been identified in all known yeast strains although NO has been detected in Saccharomyces cerevisiae [11] and Schizosaccharomyces pombe [12]. It has been suggested that yeast mitochondrial cytochrome $c$ oxidase (COX) can catalyze the reduction of nitrite to NO [13], implying NO not from NOS may be employed for yeast signaling.

It seems that NO-enhanced mitochondrial biogenesis during CR exposure is an acceptable conclusion drawn for CR-mediated lifespan extension because augmented respiratory activity has been found to correlate with longevity in yeast, fruit flies, mice, and rats $[14,15]$. However, a recent report has addressed chronic CR preserves mitochondrial function in aging without increasing mitochondrial biogenesis [16]. Other new reports have also questioned if CR really elicits mitochondrial biogenesis [17,18]. Therefore, how to decipher the discrepancy regarding mitochondrial biogenesis is still an open question.

From the observation that the increases in mitochondrial translation and oxygen consumption are manifested during logarithmic and early postdiauxic growth stages in yeast [19], we proposed here a hypothesis of "dual-phase responses", which annotates the active reactions of yeast upon CR by the first phase of "mitochondrial enhancement" (ME), or a respiratory burst phase, and the second phase of "post-mitochondrial enhancement" (PME), or a respiratory decay phase. While ME occurs only in the early CR phase (short-term or acute CR), PME maintains in the late CR phase (life-long or chronic $\mathrm{CR}$ ). Because $\mathrm{CR}$ can trigger hydrogen peroxide $\left(\mathrm{H}_{2} \mathrm{O}_{2}\right)$ burst and induce superoxide dismutase (SOD) overexpression [20], and NO can reversibly bind to the heme moiety of COX [21], we assume CR-triggered $\mathrm{NO}$ may interact with $\mathrm{COX}$ to result in $\mathrm{H}_{2} \mathrm{O}_{2}$ generation and SOD induction through mitochondrial uncoupling, thereby scavenging reactive oxygen species (ROS), attenuating oxidative stress, guiding metabolic conversion, and eventually extending lifespan.

To verify the above preposition, we used artesunate (ART), a semi-synthetic derivative of the antimalarial artemisinin enabling conjugation to the heme moiety within $\mathrm{COX}$ to simulate the interaction of $\mathrm{NO}$ with $\mathrm{COX}$ during $\mathrm{CR}$ exposure. Also, we used $\mathrm{H}_{2} \mathrm{O}_{2}$ to testify the consequence of NO-COX interaction. Our previous work has convinced ART can induce NOS and catalase (CAT), and lead to the generation of $\mathrm{NO}$ and $\mathrm{H}_{2} \mathrm{O}_{2}$ by covalently conjugating the heme moiety of those hemoenzymes, suggesting ART may behave as the $\mathrm{NO}$ and $\mathrm{H}_{2} \mathrm{O}_{2}$ inducers [22,23].

For a systematical evaluation on CR-mediated antioxidative augments and metabolic alterations, we comparatively analyzed the global expression profiles of CR, ART, or $\mathrm{H}_{2} \mathrm{O}_{2}$-treated yeast by a whole transcriptomic microarray. Among which the quantitative data from some critical genes were further confirmed by real-time fluorescent quantitative reverse transcription-polymerase chain reaction (qPCR) and enzyme activity determination. Also, ART-heme conjugation was correlated with COX upregulation and activation. We believe these results should shed light into the identification of bona fide mechanisms underlying that $\mathrm{CR}$ prolongs yeast lifespan through putative $\mathrm{NO}$ and $\mathrm{H}_{2} \mathrm{O}_{2-}$ mediated signaling cascades.

\section{Materials and methods}

\subsection{Strains, media, and culture conditions}

The budding yeast (Saccharomyces cerevisiae) strain BY4743 (Invitrogen, Carlsbad, CA, USA) was grown in YPD media (1\% yeast extract, $2 \%$ bactopeptone, and $2 \%$ glucose), either liquid or solid (2\% agar) as calorie nonrestriction (NR), while YPD media containing $0.5 \%$ glucose were included as CR. For liquid culture, yeast cells (initial $A_{600}=0.01$ ) were inoculated in $5 \mathrm{~mL}$ YPD liquid media in $25-\mathrm{mL}$ tubes and incubated at $30^{\circ} \mathrm{C}$ with shaking $(200 \mathrm{r}$ $\min ^{-1}$ ). For solid culture, a diluted overnight yeast culture (initial $A_{600}=0.05$ ) was plated on YPD solid media in $9-\mathrm{cm}$ Petri dishes and incubated at $30^{\circ} \mathrm{C}$.

\subsection{Treatment and sampling}

CR was divided into acute $\mathrm{CR}$ and chronic CR. For acute $\mathrm{CR}$, yeast was grown in liquid media containing $0.5 \%$ glucose for $12 \mathrm{~h}$ (at the logarithmic growth stage); for chronic $\mathrm{CR}$, yeast was grown in liquid media containing $0.5 \%$ glucose for several days (at the post-logarithmic growth stage). ART (Nanyao Pharmacy, Guilin, China) or $\mathrm{H}_{2} \mathrm{O}_{2}$ was used to treat yeast on the 3rd day for microarray and qPCR, or on the 7th day for CLS analysis. Fresh yeast cultures were used for determination of enzyme activities and detection of ART-heme adducts.

\subsection{CLS analysis}

A single yeast colony was inoculated into $5 \mathrm{~mL}$ YPD containing $2 \%$ glucose (NR) or containing $0.5 \%$ glucose (CR) in a $25-\mathrm{mL}$ tube, and incubated at $30^{\circ} \mathrm{C}$ with shaking $(200 \mathrm{r}$ $\left.\min ^{-1}\right)$. An aliquot of yeast cultures was sampled from each tube at different intervals for CLS analysis. Beginning at $A_{600}=1$, a series of dilutions $\left(10,10^{2}, 10^{3}, 10^{4}\right)$ of $3 \mu \mathrm{L}$ per aliquot were prepared for plating and incubation. Colony numbers were counted after 72-h incubation.

\subsection{Determination of SOD and COX activities}

Yeast Mn-SOD and COX activities were determined using commercial kits according to the manufacturer's instructions (Jiancheng Biotech, Nanjing, China, for SOD determination; GENMED, Shanghai, China, for COX determination). SOD activity was calculated from the formula: SOD 
$\left(\mathrm{U} \mathrm{mL}{ }^{-1}\right)=\left(A_{550 \text { blank }}-A_{550 \text { test }} / A_{550 \text { blank }}\right) \times 2 \times$ reaction volume $(\mathrm{mL}) /$ sample $(\mathrm{mL})$. COX activity was calculated from the formula: $\operatorname{COX}\left(\mathrm{U} \mathrm{mL}^{-1}\right)=\left[\left(A_{550}\right.\right.$ blank $-A_{550}$ test $) \times$ reaction volume $(1 \mathrm{~mL}) \times$ dilution fold $(1$ fold $)] /[$ sample $(0.1 \mathrm{~mL}) \times$ absorbance/mmol L $\mathrm{m}^{-1}(21.84) \times$ reaction time $\left.(1 \mathrm{~min})\right]$.

\subsection{Transcriptome-wide microarray}

For microarray analysis, the Agilent array platform was employed. Sample preparation, microarray hybridization, chip scanning, image featuring, and data processing were performed based on the manufacturer's standard protocols.

Differentially expressed genes were identified through fold change filtering. Pathway analysis and gene ontology (GO) analysis were applied to determine the roles of these differentially expressed genes played in these biological pathways or GO terms. Hierarchical clustering was performed to show the distinguishable gene expression profiling between two samples.

\section{6 qPCR}

Total RNAs were extracted from yeast cells by a Trizol method for RT-PCR amplification. Sequences of primers for RT-PCR are listed below: KSS1F: GCGATTTTGGACTAGCGAGG; KSS1R: TTATCTCGGGTGCCCTGTAC; COX1F: GTGGTTTAAC TGGTGTTGCCT; COX1R: TCATCCTGCGAAAGCATCAG; SOD2F: AGTTTGGCAGTCTGGAC GAG; SOD2R: GGCAACTAGAGGAACTAGTG. All primers were synthesized by Invitrogen. The expression levels were compared between a treatment group and a control group as up/downregulation folds based on the analytic method of $2^{-\Delta \Delta C_{\mathrm{t}}}$, in which $\Delta \Delta C_{\mathrm{t}}=$ [target gene (treatment group)/target gene (control group)]/[housekeeping gene (treatment group)/house-keeping gene (control group)].

\subsection{Spectrophotometric monitoring of ART-heme ad- ducts}

In each group, $50 \mathrm{~mL}$ yeast cells $\left(A_{600}=1\right)$ was lysed with a freeze-thaw cycle $\left(-30^{\circ} \mathrm{C}\right.$ for $15 \mathrm{~min}, 80^{\circ} \mathrm{C}$ for $\left.15 \mathrm{~s}\right)$ that was repeated four times. Next, $1 \mathrm{~mL}$ supernatant was sampled for absorbance measurement at 415 and $476 \mathrm{~nm}$, indicating the presence of heme and ART-heme adducts, respectively.

\section{Results}

\subsection{ART and $\mathrm{H}_{2} \mathrm{O}_{2}$ mimic CR to extend CLS in a dose-dependent manner}

To replay the episode of CR-extended lifespan, yeast cells were incubated on the cultural plates containing $0.5 \%$ glu- cose. In parallel, yeast cultural media were supplemented with different doses of ART to mimic CR's effects. Low doses $\left(0.1\right.$ and $\left.0.5 \mu \mathrm{mol} \mathrm{L^{-1 }}\right)$ of ART allow the significant increases of survived cells when colonies were counted on the 9th, 16th and 20th day after ART treatment. Among those, CR, $0.1 \mu \mathrm{mol} \mathrm{L}{ }^{-1}$ ART, $0.5 \mu \mathrm{mol} \mathrm{L}{ }^{-1}$ ART, and NR give rise to viable cells from higher percentages to lower ones (Figure 1A and B). In contrast, high doses (5, 25, and $50 \mu \mathrm{mol} \mathrm{L} \mathrm{L}^{-1}$ ) of ART decrease the survivable cell numbers as observed on the 9th, 14th and 16th day following ART treatment (Figure 1C and D). These results indicate low-dose ART extends CLS as a functional CR mimetic, whereas high-dose ART shortens CLS most likely due to cell death.

To disclose the involvement of $\mathrm{H}_{2} \mathrm{O}_{2}$ in CR-mediated lifespan extension, yeast cells were treated by different concentrations of $\mathrm{H}_{2} \mathrm{O}_{2}$. After CLS assay, $\mathrm{H}_{2} \mathrm{O}_{2}$ in low concentrations $\left(0.1,0.5\right.$ and $\left.20 \mu \mathrm{mol} \mathrm{L}{ }^{-1}\right)$ slightly extends CLS on the 9th, 16th and 20th day without significant difference from NR (Figure 1E and F). Although $\mathrm{H}_{2} \mathrm{O}_{2}$ affects yeast lifespan in a dose-dependent manner, and also implies oxidative stress-induced antioxidative responses may be engaged in anti-aging effects in yeast. Further validation of the anti-aging effect is needed.

\subsection{Induction of differentially expressed genes is par- tially overlapped and up/downregulation of specific pathway genes is similar in different treatment groups}

To provide evidence supporting ART or $\mathrm{H}_{2} \mathrm{O}_{2}$ may exhibit similarity with $\mathrm{CR}$ in differentially expressed yeast genes, $\mathrm{CR}, 25 \mu \mathrm{mol} \mathrm{L}{ }^{-1}$ ART, or $20 \mu \mathrm{mol} \mathrm{L} \mathrm{H}_{2} \mathrm{O}_{2}$-inducible yeast transcripts from whole-transcriptome expression profiling were compared. From the hierarchical clustering diagram based on all target values, transcripts induced by CR, ART, or $\mathrm{H}_{2} \mathrm{O}_{2}$ exhibit significant difference from those induced by NR. While transcripts from CR are partially common with ART or $\mathrm{H}_{2} \mathrm{O}_{2}$, those between ART and $\mathrm{H}_{2} \mathrm{O}_{2}$ are more similar than CR (Figure S1A in Supporting Information).

Upon treatments, CR, $25 \mu \mathrm{mol} \mathrm{L}{ }^{-1} \mathrm{H}_{2} \mathrm{O}_{2}$, and $20 \mu \mathrm{mol}$ $\mathrm{L}^{-1}$ ART respectively result in the induction of 1368,1119 , and 662 genes among 6256 tested yeast genes in total. While 559 transcripts between $\mathrm{CR}$ and $\mathrm{H}_{2} \mathrm{O}_{2}$ or 400 transcripts between CR and ART are common, other inducible transcripts are unique in CR (Figure S1B in Supporting Information). Among those differentially expressed genes, CR induces the most different genes, whereas ART induces the least ones. Additionally, significantly up/downregulated common genes are less in CR-ART comparison than in $\mathrm{CR}-\mathrm{H}_{2} \mathrm{O}_{2}$ comparison (Figure $\mathrm{S} 1 \mathrm{C}$ in Supporting Information).

According to the definition of KEGG pathways (http://www.genome.jp/kegg/), gene oncology data were analyzed and up/downregulated pathway genes identified in the $\mathrm{CR}, 25 \mu \mathrm{mol} \mathrm{L}{ }^{-1}$ ART, or $20 \mu \mathrm{mol} \mathrm{L}^{-1} \mathrm{H}_{2} \mathrm{O}_{2}$ group. In 

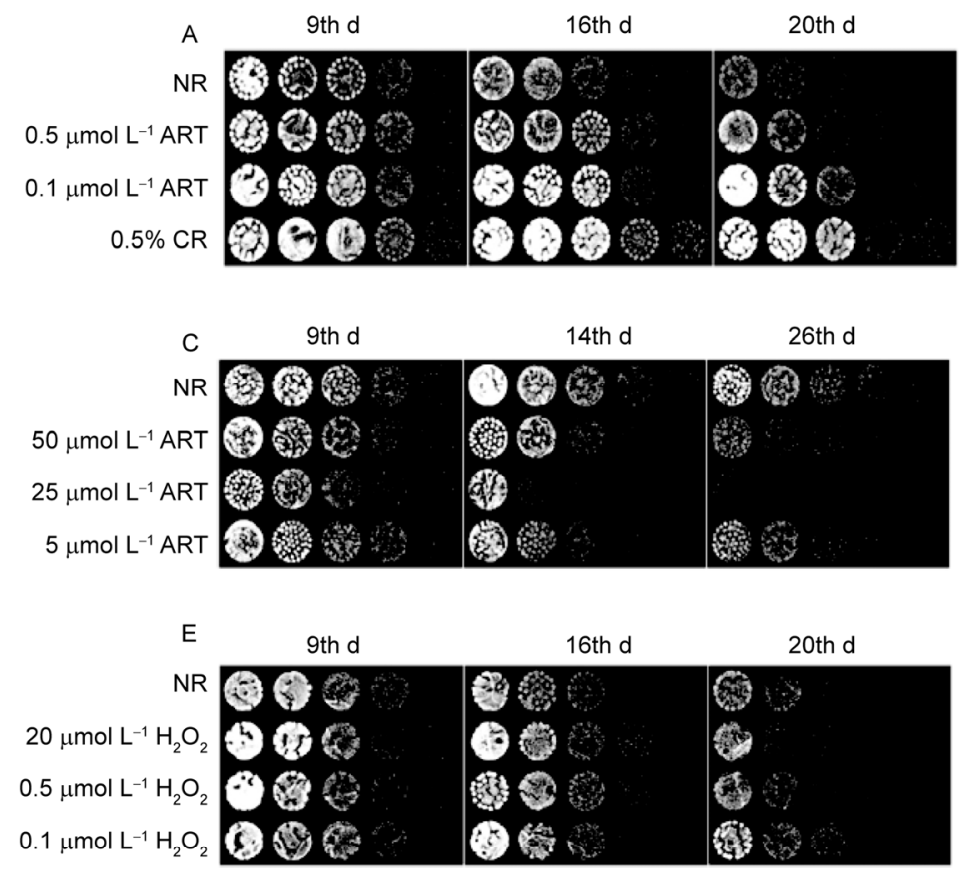
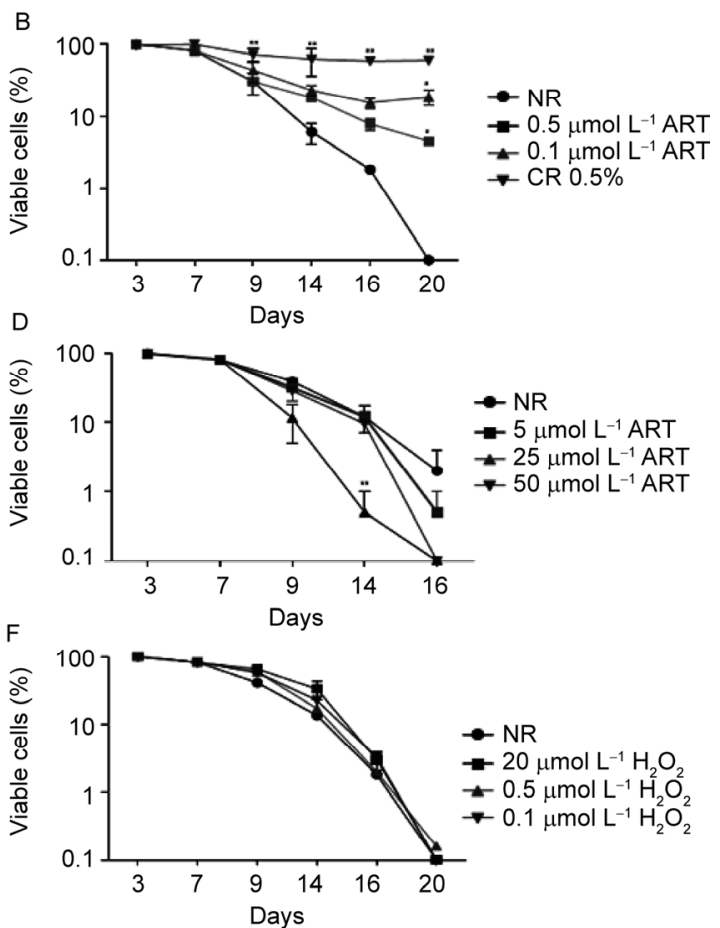

Figure 1 ART or $\mathrm{H}_{2} \mathrm{O}_{2}$ mimics $\mathrm{CR}$ to extend CLS in a dose-dependent manner. A and B, Colony counts and survival curves of viable yeast cells treated by low-dose ART, with inclusion of $0.5 \%$ CR. C and D, Colony counts and survival curves of viable yeast cells treated by high-dose ART. E and F, Colony counts and survival curves of viable yeast cells treated by $\mathrm{H}_{2} \mathrm{O}_{2}$. NR, $2 \%$ glucose; CR, $0.5 \%$ glucose. Solid cultures were prepared by plating liquid cultures on media in different culture intervals (days after treatment). The parallel plates illustrated in each figure (A, C and E) were prepared by inoculating different cultural dilutions, from left to right, in $0,10 \times, 10^{2} \times, 10^{3} \times$ and $10^{4} \times{ }^{*}, P<0.05 ; * *, P<0.01(n=3)$.

total, 34 KEGG pathways were depicted for all treatments based on whether those genes are up/downregulated for two folds as NR. Among which CR induces 14 downregulated pathways and 13 upregulated pathways (Figure S2A in Supporting Information); $\mathrm{H}_{2} \mathrm{O}_{2}$ downregulates seven pathways and upregulates five pathways (Figure S2B in Supporting Information); and ART only enables the downregulation of five pathways and the upregulation of two pathways (Figure S2C in Supporting Information). For all treatments, the ribosomal protein pathway and the MAPK signaling pathway are downregulated, whereas meiosis pathway is upregulated.

\subsection{Metabolic alterations from biosynthesis to degra- dation of major metabolites are induced by treatments}

Although all microarray data of inducible pathway genes are available for different treatments, some of which have not been displayed in gene ontology diagrams because of undefined significance (less than two-fold up/downregulation) as compared with NR. To clearly address ART or $\mathrm{H}_{2} \mathrm{O}_{2}$ mimics $\mathrm{CR}$ in the affected modes of gene expression for metabolic modulation, the actual quantitative transcript data of major metabolic pathway genes were parallelly listed for the CR, $25 \mu \mathrm{mol} \mathrm{L}-1$ ART, or $20 \mu \mathrm{mol} \mathrm{L}{ }^{-1} \mathrm{H}_{2} \mathrm{O}_{2}$ group (Table 1).

As a major kind of energy metabolites, glucose can be degraded through glycolysis in combination with the citrate cycle for energy production. Glucose degradation should be damped by limited glucose supply in CR, so it is reasonable that the pathway genes responsible for both glycolysis and citrate cycle are downregulated. Interestingly, $25 \mu \mathrm{mol} \mathrm{L} \mathrm{L}^{-1}$ ART and $20 \mu \mathrm{mol} \mathrm{L}{ }^{-1} \mathrm{H}_{2} \mathrm{O}_{2}$ also downregulate those glucose degradation pathway genes as well. Regarding fatty acids, another major energy metabolites, it is clear that biosynthesis pathway genes are downregulated, but degradation pathway genes are upregulated in all treatment groups, suggesting the modulation of lipids from storage to mobilization (data not listed, see [49]). Similarly, biosynthesis pathway genes for two kinds of amino acids, cystein and methionine, are downregulated, whereas degradation pathway genes for two kinds of nucleotide bases, purine and pyrimidine, are upregulated. From the above results, we can predict both protein biosynthesis and nucleic acid degradation should be attenuated or even halted. The estimation of the protein concentrations in yeast cells treated by ART or exposed to $\mathrm{CR}$ was found to significantly inhibit protein biosynthesis (data not shown).

2.4 Downregulation of protein biosynthesis pathway genes and upregulation of protein degradation pathway genes are common among treatments

To further reveal the effect of $\mathrm{CR}, \mathrm{ART}$, or $\mathrm{H}_{2} \mathrm{O}_{2}$ on protein 
Table 1 Up/downregulation of pathway genes responsible for biosynthesis or degradation of major metabolites by $\mathrm{CR}$, ART, or $\mathrm{H}_{2} \mathrm{O}_{2}{ }^{\text {a) }}$

\begin{tabular}{|c|c|c|c|c|}
\hline \multirow{2}{*}{ Metabolites } & \multirow{2}{*}{ Pathways \& genes } & \multicolumn{3}{|c|}{ Up/downregulation folds } \\
\hline & & $\mathrm{CR}$ & ART & $\mathrm{H}_{2} \mathrm{O}_{2}$ \\
\hline \multicolumn{5}{|c|}{ Glycolysis/Gluconeogenesis } \\
\hline \multirow{23}{*}{ Glucose } & $\operatorname{Acs} 2 p$ & -17.28 & -2.63 & -3.02 \\
\hline & Adh $6 p$ & -6.18 & -1.54 & -3.06 \\
\hline & Ald $3 p$ & -1.49 & -1.83 & 2.13 \\
\hline & Enolp & -1.75 & -1.38 & -2.26 \\
\hline & $P d c 6 p$ & -4.88 & -2.16 & -3.71 \\
\hline & $\operatorname{Pgm} 2 p$ & -1.68 & -1.74 & -2.02 \\
\hline & $P y k 2 p$ & -1.27 & -1.72 & -2.20 \\
\hline & $\operatorname{Tdh} 2 p$ & -4.32 & -4.17 & -12.62 \\
\hline & $T d h 3 p$ & -1.49 & -2.47 & -10.36 \\
\hline & \multicolumn{4}{|l|}{ Citrate cycle } \\
\hline & Acolp & -1.71 & -1.43 & -1.63 \\
\hline & Cit $2 p$ & 1.04 & 1.11 & 1.06 \\
\hline & Fumlp & -2.55 & -1.16 & -1.20 \\
\hline & $\operatorname{Idh} 1 p$ & -3.26 & 1.08 & 1.06 \\
\hline & Kgdlp & -1.58 & -1.26 & -1.28 \\
\hline & $K g d 2 p$ & -1.51 & -1.15 & -1.29 \\
\hline & Latlp & 1.00 & 1.32 & 1.39 \\
\hline & $L s c 2 p$ & -1.63 & 1.03 & -1.32 \\
\hline & $M d h 3 p$ & 1.55 & 1.39 & 1.39 \\
\hline & Pcklp & -2.21 & -1.19 & -1.26 \\
\hline & $P d b 1 p$ & -1.60 & -1.04 & -1.14 \\
\hline & $P y c 2 p$ & -1.73 & 1.46 & 1.33 \\
\hline & $S d h 4 p$ & -1.58 & -1.12 & -1.17 \\
\hline \multirow{12}{*}{$\begin{array}{l}\text { Amino } \\
\text { acids }\end{array}$} & \multicolumn{4}{|c|}{ Cysteine and methionine biosynthesis } \\
\hline & Arosp & -4.17 & -1.46 & -1.54 \\
\hline & Cys $3 p$ & -3.91 & -2.54 & -4.85 \\
\hline & $\operatorname{Hom} 2 p$ & -2.09 & -1.19 & 1.04 \\
\hline & $\operatorname{Irc} 7 p$ & -14.85 & -1.89 & -2.98 \\
\hline & Met6p & -2.24 & -1.68 & -1.88 \\
\hline & Sahlp & -7.18 & -1.29 & -1.29 \\
\hline & Samlp & -4.11 & -1.94 & -1.43 \\
\hline & $\operatorname{Sam} 4 p$ & -4.94 & -2.27 & -2.64 \\
\hline & Spe $2 p$ & -2.84 & -1.38 & -1.32 \\
\hline & Spe $4 p$ & -2.02 & -1.31 & -1.19 \\
\hline & Utr4p & -2.71 & -1.02 & -1.05 \\
\hline \multicolumn{5}{|c|}{ Purine and pyrimidine degradation } \\
\hline \multirow{16}{*}{ Nucleotides } & Apalp & 2.73 & 1.84 & 2.40 \\
\hline & $C d c 8 p$ & 2.25 & 1.11 & -1.19 \\
\hline & Dal3p & 2.70 & 4.26 & 4.10 \\
\hline & $D b p 3 p$ & 2.24 & 3.34 & 4.70 \\
\hline & $D b p 4 p$ & 3.28 & 1.47 & 1.65 \\
\hline & Gudlp & 2.37 & 1.90 & 2.00 \\
\hline & $H n t 2 p$ & 2.66 & 2.82 & 3.20 \\
\hline & Met $14 p$ & 3.28 & 1.46 & 1.74 \\
\hline & $\operatorname{Prs} 2 p$ & 2.14 & 1.50 & 1.61 \\
\hline & $R n r 3 p$ & 2.02 & 1.02 & 1.30 \\
\hline & Rpa12p & 2.08 & 1.11 & 2.07 \\
\hline & Rpa34p & 2.50 & -1.20 & 1.78 \\
\hline & Rpa $43 p$ & 2.83 & 1.29 & 2.46 \\
\hline & $R p c 31 p$ & 2.24 & 1.10 & 1.08 \\
\hline & $R p c 53 p$ & 2.75 & 1.41 & 2.06 \\
\hline & $\operatorname{Tr} r 2 p$ & 3.18 & 1.24 & 1.26 \\
\hline
\end{tabular}

a) CR, $0.5 \%$ glucose; ART, $25 \mu \mathrm{mol} \mathrm{L}{ }^{-1} ; \mathrm{H}_{2} \mathrm{O}_{2}: 20 \mu \mathrm{mol} \mathrm{L} \mathrm{L}^{-1}$.

biosynthesis and degradation, we compared the transcriptomic data of ribosomal protein genes including ribosomal protein large subunit genes $(R p l)$ and ribosomal protein small subunit genes (Rps) after treatments by $25 \mu \mathrm{mol} \mathrm{L}{ }^{-1}$
ART or $20 \mu \mathrm{mol} \mathrm{L} \mathrm{L}^{-1} \mathrm{H}_{2} \mathrm{O}_{2}$. As consequences, more than 70 Rpl/Rps and other related genes are downregulated, among which CR leads to more remarkable downregulation. In particular, while CR downregulates Rpp $2 a$ for 38 folds, 25 $\mu$ mol L ${ }^{-1}$ ART or $20 \mu$ mol L ${ }^{-1} \mathrm{H}_{2} \mathrm{O}_{2}$ downregulates this gene for 50 folds and 51 folds, respectively (Table 2). These results indicate the de novo biosynthesis of proteins is potently inhibited during $\mathrm{CR}$ exposure, and ART or $\mathrm{H}_{2} \mathrm{O}_{2}$ can simulate $\mathrm{CR}$ to downregulate ribosomal protein genes and hence to repress translation occurring in ribosomes.

Accordingly, 20 ribosome biogenesis genes are highly upregulated in CR, $25 \mu \mathrm{mol} \mathrm{L}{ }^{-1}$ ART, or $20 \mu \mathrm{mol} \mathrm{L}{ }^{-1} \mathrm{H}_{2} \mathrm{O}_{2}$ groups (Figure 2A), perhaps reflecting a feedback outcome following the downregulation of ribosomal protein genes. Not surprisingly, upregulation of ribosome biogenesis genes is much enhanced in the CR group because its ribosomal protein genes are extremely downregulated. At the same time, we analyzed the impact of treatments on controlled protein degradation through ubiquitylation. Among 40 ubiquitylation genes $(\mathrm{Ubi})$, most of them are upregulated by $\mathrm{CR}, 25 \mu \mathrm{mol} \mathrm{L}{ }^{-1} \mathrm{ART}$, or $20 \mu \mathrm{mol} \mathrm{L}{ }^{-1} \mathrm{H}_{2} \mathrm{O}_{2}$, indicating selective protein degradation becomes extensive in order to reutilize amino acids released from degraded proteins (Figure 2B). Furthermore, we also found autophagy-involved 27 Atg genes are mostly upregulated by all treatments (Figure 2C), suggesting augmented autophagy may help yeast to cope with nutritional stress.

\subsection{Oxidative phosphorylation is attenuated, and $\beta$-oxidation is accelerated, but antioxidation is selectively activated in different treatments}

The metabolic flux of glucose generally flows from the cytosolic glycolysis pathway to the mitochondrial citrate cycle, and is further converged into the coupled oxidative phosphorylation pathway. Because glycolysis pathway genes and citrate cycle genes are downregulated by $\mathrm{CR}, 25 \mu \mathrm{mol}$ $\mathrm{L}^{-1}$ ART, or $20 \mu \mathrm{mol} \mathrm{L}{ }^{-1} \mathrm{H}_{2} \mathrm{O}_{2}$, it can be predicted that oxidative phosphorylation pathway genes should be accordingly downregulated by those treatments. Indeed, mitochondrial signature genes encoding COX (complex IV), $\mathrm{F}_{1} \mathrm{~F}_{0}$-ATP synthase (Complex V) and other associated proteins are downregulated in each group (Figure 3A). As noted, the expression levels of those genes are much lower in the CR group than in $25 \mu \mathrm{mol} \mathrm{L}{ }^{-1}$ ART and $20 \mu \mathrm{mol} \mathrm{L} \mathrm{L}^{-1}$ $\mathrm{H}_{2} \mathrm{O}_{2}$ groups.

The medium- and long-chain fatty acids can be degraded by peroxisomal $\beta$-oxidation for energy production. The medium chain (C9-C13) fatty acyl-CoA synthetase gene FAA2 and long chain (C12-C16) fatty acyl-CoA synthetase gene FAA4 are upregulated upon CR exposure. While $25 \mu \mathrm{mol}$ $\mathrm{L}^{-1}$ ART upregulates FAA2 and FAA4, $20 \mu \mathrm{mol} \mathrm{L} \mathrm{L}^{-1} \mathrm{H}_{2} \mathrm{O}_{2}$ mildly downregulates $F A A 2$ and FAA4. Moreover, all treatments also upregulate the genes responsible for fatty 
Table 2 Up/downregulation of yeast ribosome degradation genes by CR, ART, or $\mathrm{H}_{2} \mathrm{O}_{2}{ }^{\text {a) }}$

\begin{tabular}{|c|c|c|c|}
\hline Gene names & $\mathrm{CR}$ & ART & $\mathrm{H}_{2} \mathrm{O}_{2}$ \\
\hline Mnpl & -2.62 & 1.11 & 1.01 \\
\hline Mrp4 & -2.25 & 1.22 & 1.09 \\
\hline Mrpl11 & -2.08 & -1.19 & -1.06 \\
\hline Mrpl6 & -2.08 & -1.44 & -1.61 \\
\hline Mrpl7 & -3.35 & -1.41 & -1.64 \\
\hline Mrps9 & -2.25 & -1.58 & -2.36 \\
\hline Rpl11a & -2.72 & -2.96 & -2.28 \\
\hline Rpl11b & -2.26 & -2.68 & -1.87 \\
\hline Rpl13a & -2.50 & -2.19 & -1.56 \\
\hline Rpll3b & -2.03 & -1.33 & -1.08 \\
\hline Rpl14a & -2.68 & -3.02 & -1.41 \\
\hline$R P L 16 b$ & -2.09 & -1.46 & -1.16 \\
\hline Rpl17a & -2.48 & -1.93 & -1.45 \\
\hline Rpl17b & -3.35 & -3.18 & -2.24 \\
\hline Rpl18a & -4.88 & -3.99 & -2.98 \\
\hline Rpl18b & -2.71 & -4.25 & -4.01 \\
\hline Rplla & -3.05 & -2.32 & -2.10 \\
\hline Rpllb & -3.08 & -2.22 & -1.90 \\
\hline Rpl2Ob & -2.05 & -1.46 & -1.02 \\
\hline Rpl21a & -2.57 & -2.64 & -1.94 \\
\hline Rpl22a & -2.16 & -1.87 & -1.19 \\
\hline$R p l 23 a$ & -2.38 & -1.75 & -1.20 \\
\hline$R p l 23 b$ & -3.28 & -2.48 & -1.61 \\
\hline$R p l 24 a$ & -3.57 & -3.13 & -1.70 \\
\hline$R p l 24 b$ & -3.48 & -2.88 & -2.22 \\
\hline Rpl25 & -2.03 & -1.45 & 1.04 \\
\hline Rpl26a & -2.79 & -2.31 & -1.86 \\
\hline$R p l 26 b$ & -2.45 & -2.18 & -1.30 \\
\hline$R p l 2 a$ & -3.58 & -2.79 & -2.63 \\
\hline$R p l 2 b$ & -4.11 & -2.50 & -2.35 \\
\hline Rpl3 & -2.42 & -2.24 & -1.83 \\
\hline Rpl30 & -2.57 & -2.10 & -1.62 \\
\hline Rpl31a & -2.13 & -1.52 & 1.06 \\
\hline Rpl31b & -2.57 & -3.11 & -1.77 \\
\hline Rpl32 & -2.12 & -1.96 & -1.50 \\
\hline Rpl33a & -2.29 & -1.33 & 1.26 \\
\hline Rpl33b & -2.49 & -1.65 & 1.10 \\
\hline Rpl35a & -2.27 & -1.67 & -1.16 \\
\hline Rpl35b & -2.02 & -1.79 & -1.19 \\
\hline$R p l 36 b$ & -2.00 & -1.62 & -1.06 \\
\hline Rpl43a & -2.03 & -1.64 & -1.14 \\
\hline Rpl6b & -2.76 & -2.88 & -2.24 \\
\hline$R p l 7 a$ & -4.84 & -4.73 & -5.89 \\
\hline RppO & -2.38 & -1.60 & -1.50 \\
\hline Rppla & -2.81 & -1.89 & -1.30 \\
\hline Rpplb & -2.65 & -2.08 & -1.61 \\
\hline$R p p 2 a$ & -38.04 & -50.24 & -51.05 \\
\hline$R p p 2 b$ & -2.57 & -1.15 & -1.04 \\
\hline$R p s O b$ & -2.72 & -2.00 & -1.58 \\
\hline Rps11a & -2.72 & -2.80 & -2.32 \\
\hline Rps11b & -5.22 & -3.91 & -4.46 \\
\hline Rps14a & -2.05 & -1.33 & 1.06 \\
\hline Rps $14 b$ & -3.69 & -6.89 & -7.56 \\
\hline Rps15 & -2.00 & -1.61 & -1.37 \\
\hline Rps16a & -2.39 & -1.72 & -1.35 \\
\hline
\end{tabular}

(To be continued on the next column)

\begin{tabular}{|c|c|c|c|}
\hline Gene names & $\mathrm{CR}$ & ART & $\mathrm{H}_{2} \mathrm{O}_{2}$ \\
\hline Rps 17a & -2.77 & -1.69 & -1.18 \\
\hline Rps $17 b$ & -2.03 & -1.39 & -1.02 \\
\hline Rps18a & -2.66 & -2.21 & -1.40 \\
\hline Rps18b & -7.37 & -5.76 & -4.95 \\
\hline Rps $19 b$ & -2.65 & -1.69 & -1.15 \\
\hline Rpsla & -3.59 & -3.99 & -3.70 \\
\hline Rpslb & -2.55 & -2.21 & -1.55 \\
\hline Rps $21 b$ & -2.58 & -1.94 & 1.08 \\
\hline Rps $22 a$ & -2.93 & -1.99 & -1.33 \\
\hline$R p s 22 b$ & -2.04 & -2.78 & -2.42 \\
\hline Rps $28 b$ & -2.82 & -3.49 & -4.22 \\
\hline Rps $4 a$ & -3.46 & -3.73 & -4.97 \\
\hline$R p s 4 b$ & -2.02 & -1.97 & -1.76 \\
\hline Rps $8 a$ & -4.00 & -2.79 & -2.63 \\
\hline$R p s 8 b$ & -3.19 & -3.20 & -2.50 \\
\hline$R p s 9 b$ & -2.49 & -2.76 & -1.85 \\
\hline
\end{tabular}

a) CR, $0.5 \%$ glucose; ART, $25 \mu \mathrm{mol} \mathrm{L}{ }^{-1} ; \mathrm{H}_{2} \mathrm{O}_{2}, 20 \mu \mathrm{mol} \mathrm{L}{ }^{-1}$.

acid transport, processing, and degradation, including IDP3 for the utilization of saturated fatty acids, POXI and SPS19 for $\beta$-oxidation, and PXA1 and PXA2 for the import of long chain fatty acids (Figure 3B). These results show fatty acids from storage lipids should contribute to energy generation through degradation by the peroxisomal $\beta$-oxidation enzymes under the present treatment condition.

The analytic data from transcriptomic microarray indicate $\mathrm{H}_{2} \mathrm{O}_{2}$ degradation-responsible antioxidant genes, such as $\mathrm{Ctal}$ encoding mitochondria-localized catalase and Gpx2 encoding cytosolic glutathione peroxidase (GPX), are upregulated by $\mathrm{CR}, 25 \mu \mathrm{mol} \mathrm{L} \mathrm{L}^{-1}$ ART, or $20 \mu \mathrm{mol} \mathrm{L} \mathrm{L}_{2}^{-1} \mathrm{H}_{2}$. In contrast, $\mathrm{H}_{2} \mathrm{O}_{2}$ generation-responsible antioxidant genes, such as $\operatorname{Sod} 1$ and $\operatorname{Sod} 2$ separately coding for cytosolic and mitochondrial superoxide dismutases $(\mathrm{Cu} / \mathrm{Zn}-\mathrm{SOD}$ and Mn-SOD), are downregulated by CR, ART or $\mathrm{H}_{2} \mathrm{O}_{2}$, implying the main type of reactive oxygen species (ROS) at this stage is $\mathrm{H}_{2} \mathrm{O}_{2}$ other than the superoxide anion $\left(\mathrm{O}_{2}^{-}\right)$. Besides, other antioxidant enzyme-encoding genes are either upregulated (Trx3) or downregulated (Gto3 and Dot5) in different treatment groups (Table 3). Additionally, elevation of the expression levels of peroxisome pathway genes such as CTA1 in all treatment groups seems to support the above deduction that $\mathrm{H}_{2} \mathrm{O}_{2}$ becomes the major kinds of ROS (Figure 3B).

\subsection{Expression fluctuations of $\operatorname{Cox} 1$ and $\operatorname{Sod} 2$ reflect a mode of dual-phase responses}

Because transcriptomic data showing the downregulation of oxidative phosphorylation and antioxidant genes were analyzed by sampling yeast in the post-logarithmic growth stage, we predict those genes should be upregulated in logarithmic yeast cells. To verify this prediction, we quantified Coxl and Sod2 mRNAs induced by various doses of ART 
A

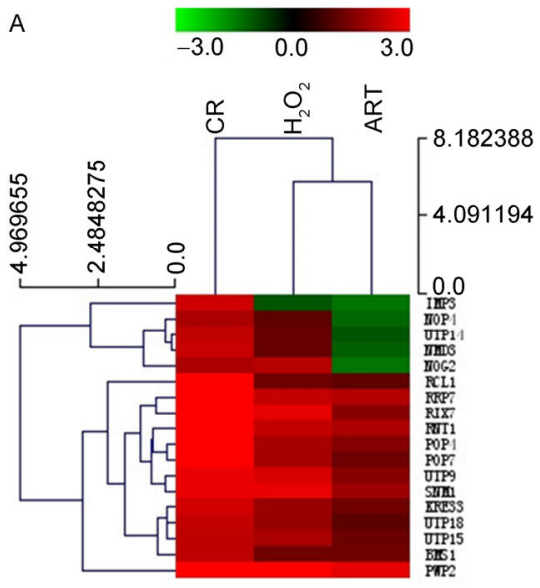

B

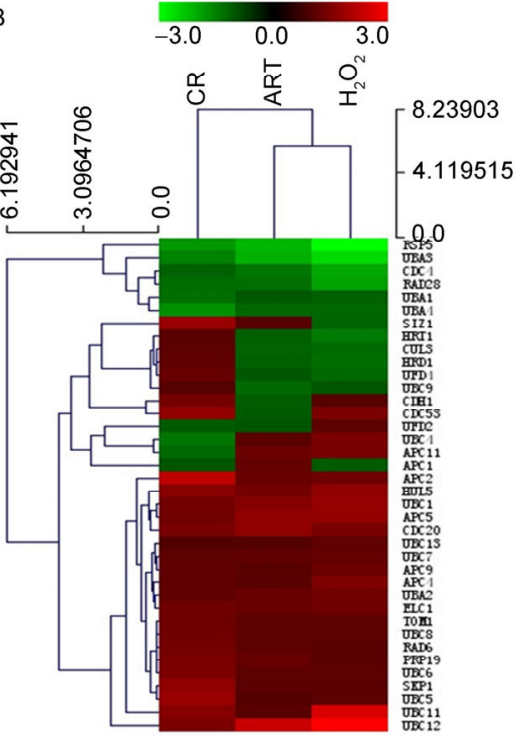

C

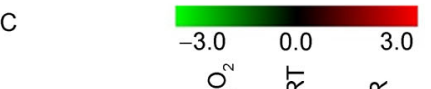

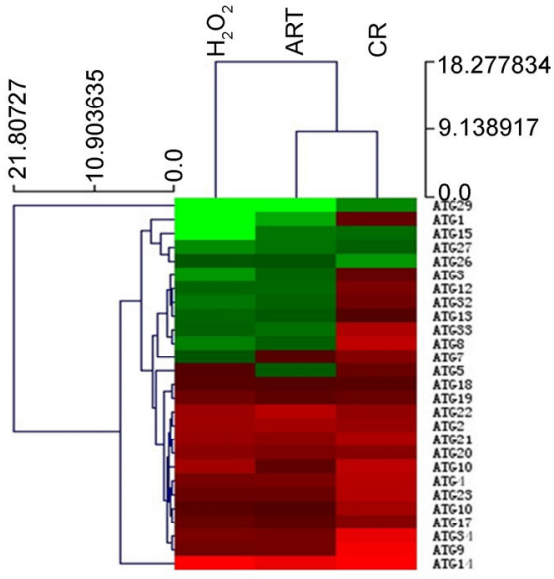

Figure 2 Transcriptome-wide profiling of protein biosynthesis and degradation-related pathway genes. A, Expression profiling of ribosome biogenesis pathway genes. B, Expression profiling of ubiquitylation pathway genes. C, Expression profiling of autophagy pathway genes. CR, $0.5 \%$ glucose; ART, 25 $\mu \mathrm{mol} \mathrm{L}{ }^{-1} ; \mathrm{H}_{2} \mathrm{O}_{2}, 20 \mu \mathrm{mol} \mathrm{L}{ }^{-1}$.
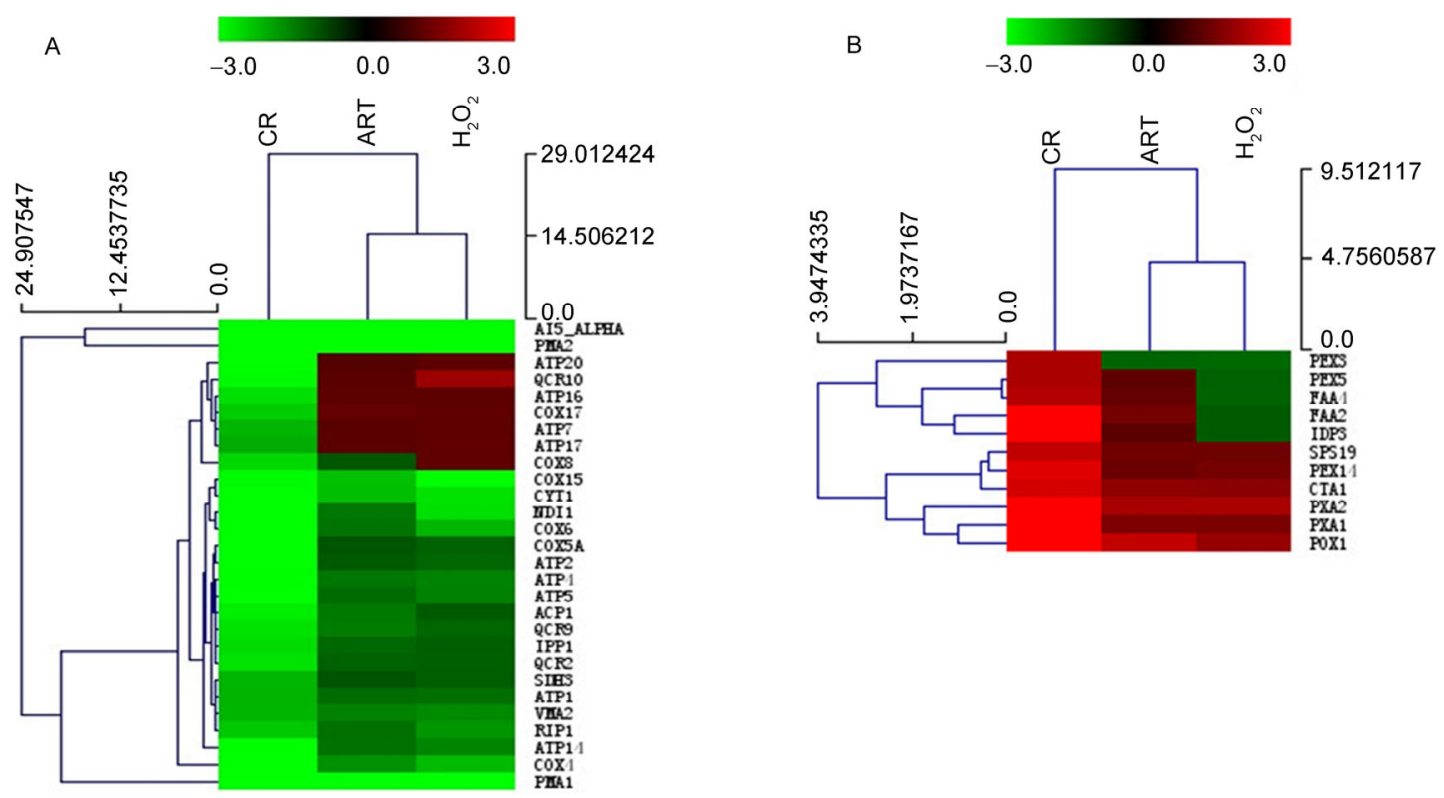

Figure 3 Expression fluctuations of oxidative phosphorylation pathway and peroxisome pathway responsible genes in yeast treated by $\mathrm{CR}$, ART, or $\mathrm{H}_{2} \mathrm{O}_{2}$. A, Oxidative phosphorylation pathway genes. B, Peroxisome pathway genes. CR, $0.5 \%$ glucose; ART, $25 \mu \mathrm{mol} \mathrm{L}^{-1} ; \mathrm{H}_{2} \mathrm{O}_{2}, 20 \mu \mathrm{mol} \mathrm{L}$.

after incubation with yeast for 10 and 30 min (Figure 4A and B). It is clear that Coxl mRNA is significantly elevated for 40-50 folds after incubation of yeast with 0.5 and 25 $\mu \mathrm{mol} \mathrm{L} \mathrm{L}^{-1}$ ART for $30 \mathrm{~min}$, whereas it is not remarkably changed in yeast treated by $20 \mu \mathrm{mol} \mathrm{L}{ }^{-1} \mathrm{H}_{2} \mathrm{O}_{2}$ for $30 \mathrm{~min}$, suggesting $\mathrm{H}_{2} \mathrm{O}_{2}$ does not directly act on the mitochondrial respiratory chains. As to Sod2 mRNA, neither ART nor $\mathrm{H}_{2} \mathrm{O}_{2}$ significantly alters its level. This is most likely because ART or $\mathrm{H}_{2} \mathrm{O}_{2}$-induced SOD has thoroughly scavenged $\mathrm{O}_{2}^{-}$, hence predisposing the downregulation of Sod2 in yeast.

To ascertain if the elevation-decline pattern is also true for Coxl-encoded mitochondrial COX, we determined COX activity in a time-course manner after treatment of yeast by ART. Consequently, a fluctuation from the initial elevation to subsequent decline occurs upon ART treatments (Figure 5A). This is also the case for Sod2-encoded mitochondrial Mn-SOD as yeast exposure to CR. While $12 \mathrm{~h}(0.5 \mathrm{~d}) \mathrm{CR}$ considerably increases the activity of Mn-SOD, $7 \mathrm{~d} \mathrm{CR}$ maintains or even decreases its activity (Figure 5B). The 
Table 3 Up/downregulation of yeast antioxidant genes by CR, ART, or $\mathrm{H}_{2} \mathrm{O}_{2}{ }^{\text {a) }}$

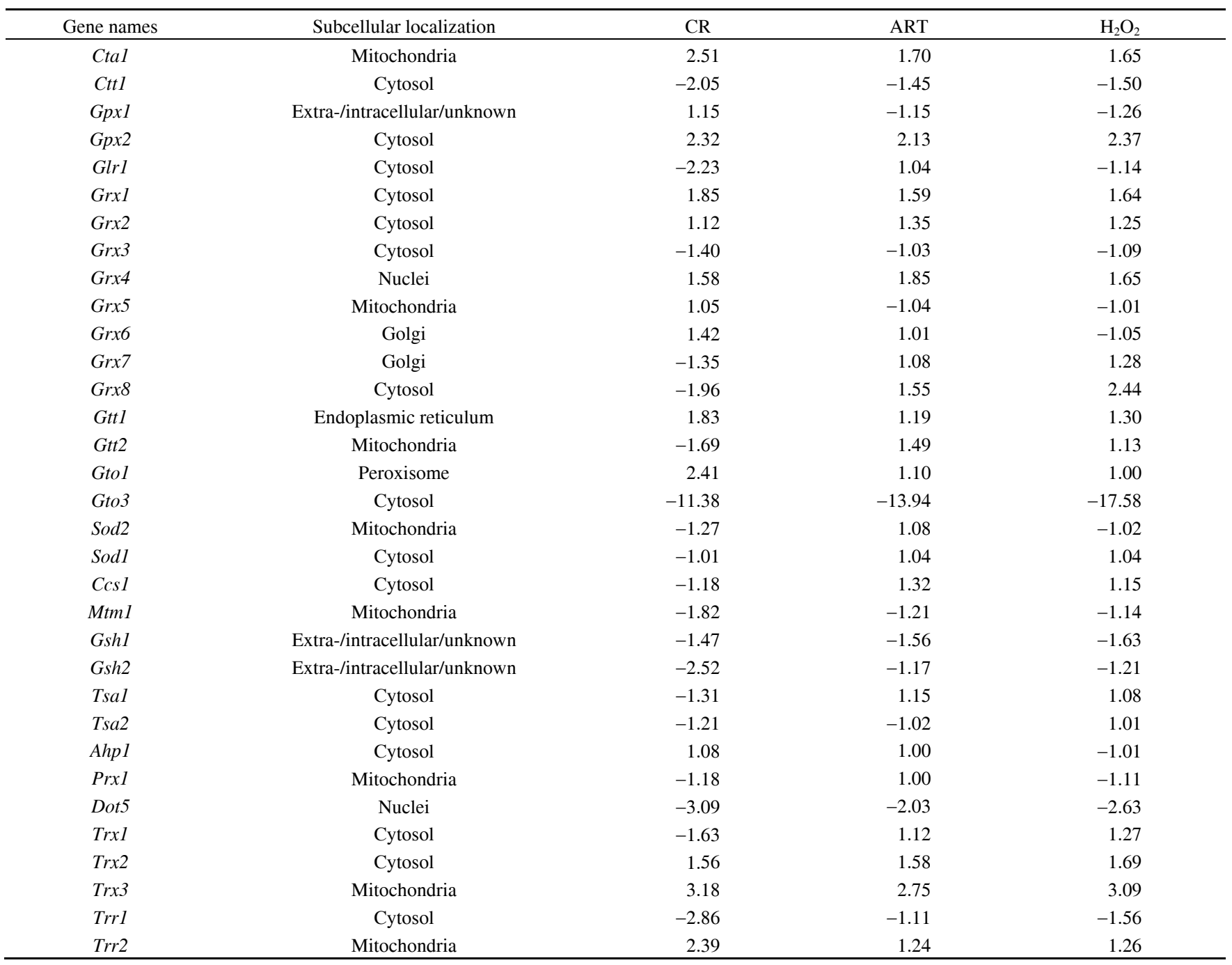

a) CR, $0.5 \%$ glucose; ART, $25 \mu \mathrm{mol} \mathrm{L}{ }^{-1} ; \mathrm{H}_{2} \mathrm{O}_{2}, 20 \mu \mathrm{mol} \mathrm{L} \mathrm{L}^{-1}$.
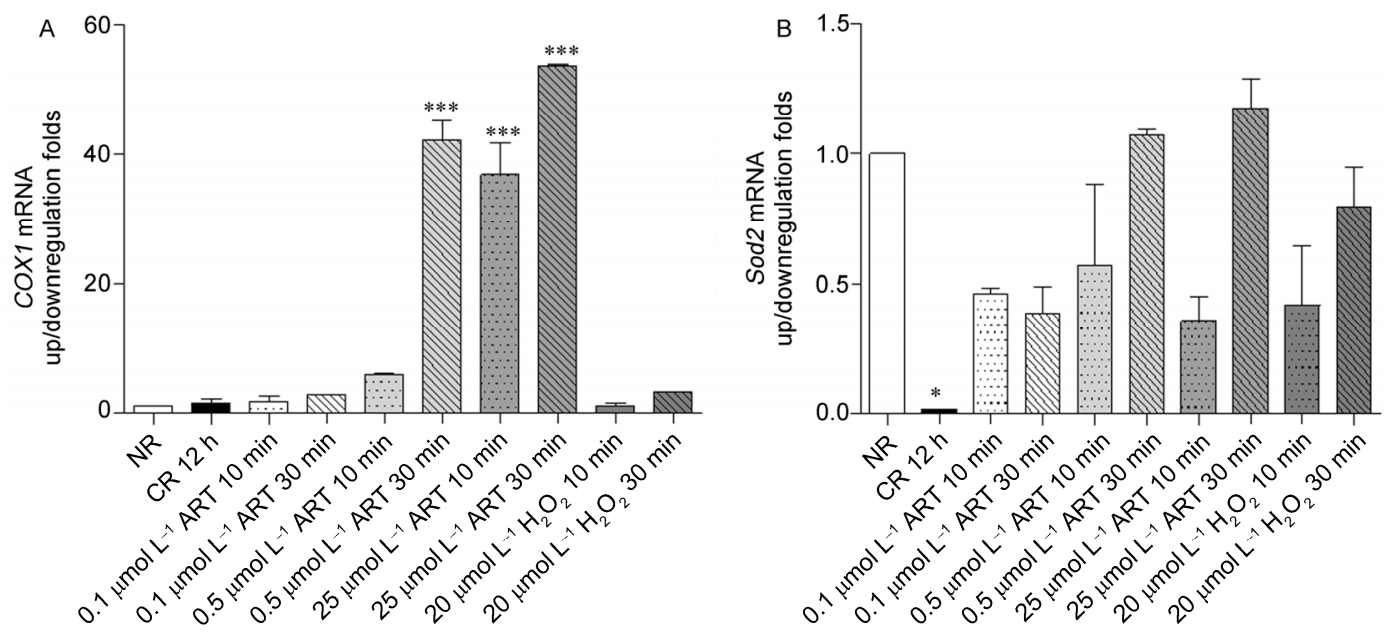

Figure 4 A logarithmic response mode of Cox 1 and Sod2 expression in yeast treated by CR, ART, or $\mathrm{H}_{2} \mathrm{O}_{2}$. A, Cox1 expression levels in logarithmic yeast cells. B, Sod 2 expression levels in logarithmic yeast cells. NR, $2 \%$ glucose; CR, $0.5 \%$ glucose. $*, P<0.05 ; * * *, P<0.001(n=3)$. 

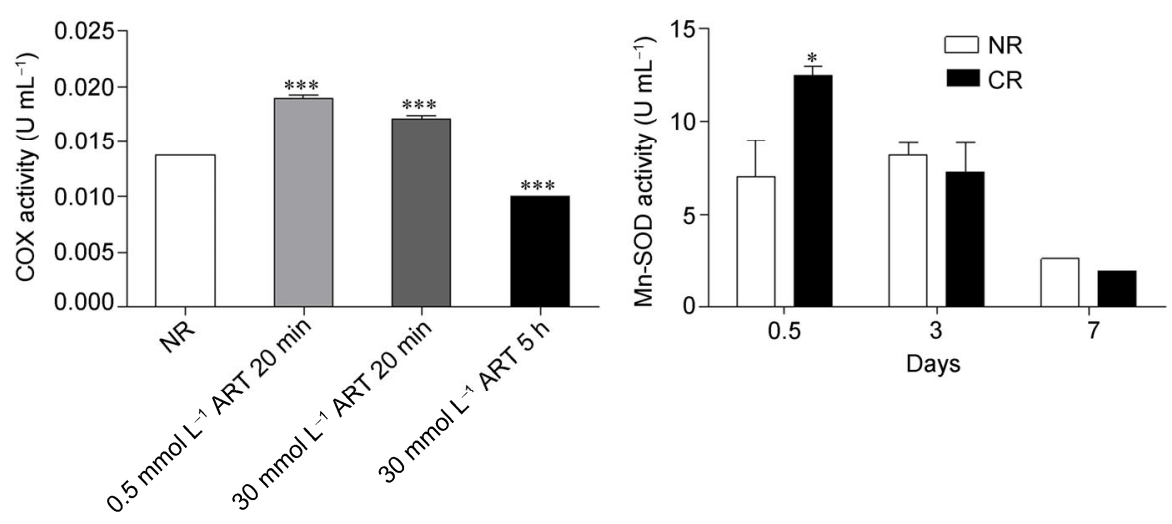

Figure 5 A dual-response mode of mitochondrial COX and Mn-SOD activities in yeast after treatments. A, COX activity in yeast treated by ART. B, Mn-SOD activity in yeast exposure to CR. NR, $2 \%$ glucose; CR, $0.5 \%$ glucose. *, $P<0.05$; ***, $P<0.001$ ( $n=6$ for COX and $n=3$ for Mn-SOD).

elevation-decline pattern for COX and Mn-SOD, therefore, may be the best annotation to our proposed dual-phase responses.

\subsection{Expression of protein kinases is differentially reg- ulated in logarithmic and post-logarithmic stages}

The synergetic declines of ATP and NADH levels should lead to the elevation of AMP/ATP and NAD ${ }^{+} / \mathrm{NADH}$ ratios, which can activate AMP-activated protein kinase (AMPK) and $\mathrm{NAD}^{+}$-dependent deacetylase Sirtuin 1 (SIRT1). As seen from Table 4, Snfl (coding for a yeast homolog of AMPK) and Sir2 (coding for a yeast homolog of SIRT1) are slightly upregulated in the CR group, but not significantly affected by $25 \mu \mathrm{mol} \mathrm{L}{ }^{-1}$ ART, or $20 \mu \mathrm{mol} \mathrm{L}^{-1} \mathrm{H}_{2} \mathrm{O}_{2}$.

Additionally, Sch9, encoding a yeast homolog of mammalian ribosomal S6 kinase 1 (S6K1), is also weakly upregulated in the $\mathrm{CR}$ group, but not changed in $25 \mu \mathrm{mol} \mathrm{L} \mathrm{L}^{-1}$ ART and $20 \mu \mathrm{mol} \mathrm{L} \mathrm{L}^{-1} \mathrm{H}_{2} \mathrm{O}_{2}$ groups. In contrast, mitogen-activated protein kinase (MAPK) pathway genes in-

Table 4 Up/downregulation of yeast protein kinase genes by CR, ART, or $\mathrm{H}_{2} \mathrm{O}_{2}$ a)

\begin{tabular}{ccrc}
\hline Genes & $\mathrm{CR}$ & $\mathrm{ART}$ & $\mathrm{H}_{2} \mathrm{O}_{2}$ \\
\hline Snf1 & 1.52 & -1.05 & -1.11 \\
Snf2 & 1.08 & -1.04 & -1.37 \\
Snf3 & 1.90 & 2.02 & 2.23 \\
Snf4 & 1.52 & -1.06 & -1.11 \\
Snf5 & 2.38 & 1.73 & 1.84 \\
Snf6 & 1.03 & -1.05 & -1.25 \\
Snf7 & 1.79 & 1.49 & 1.57 \\
Snf8 & 1.00 & -1.12 & -1.05 \\
Snf11 & 1.70 & 1.08 & -1.10 \\
Snf12 & 1.60 & 1.33 & 1.34 \\
Sir2 & 1.66 & 1.17 & -1.1 \\
Sir3 & 1.86 & 1.30 & 1.21 \\
Sir4 & 1.56 & -1.09 & -1.13 \\
Sch9 & 1.36 & -1.08 & -1.23 \\
\hline
\end{tabular}

a) CR, $0.5 \%$ glucose; ART, $25 \mu \mathrm{mol} \mathrm{L}{ }^{-1} ; \mathrm{H}_{2} \mathrm{O}_{2}, 20 \mu \mathrm{mol} \mathrm{L} \mathrm{L}^{-1}$. cluding Kss 1 and Fus3 are mostly downregulated by CR, 25 $\mu$ mol L ${ }^{-1}$ ART, or $20 \mu \mathrm{mol} \mathrm{L} \mathrm{L}^{-1} \mathrm{H}_{2} \mathrm{O}_{2}$ (Figure 6A). The downregulation of MAPK pathway genes is correlated with the upregulation of meiosis pathway genes (Figure 6B).

The two critical genes, Torl and Tor2, encoding the protein kinases, Tor $1 \mathrm{p}$ and Tor $2 \mathrm{p}$, that control cell fate and determine lifespan are also upregulated for 1.5-2 folds in all treatment groups (Figure 7A). Because Tor1p is activated via phosphorylation, we do not expect there is a correlation of Torlp activity with Torl mRNA abundance. Nevertheless, it seems the inhibition of Tor1p activity may induce Torl expression. Because transcriptomic data of Torl, Snfl, and Kss 1 are available from yeast cells collected in a post-logarithmic stage, we thought there may be a similar mode of dual-phase transversion. Therefore, we further quantified the induced expression levels of Torl, Snfl, and Kss 1 in logarithmic yeast among treatment groups. The expression pattern of Torl induced by CR, $25 \mu \mathrm{mol} \mathrm{L}{ }^{-1}$ ART, or $20 \mu \mathrm{mol} \mathrm{L} \mathrm{L}^{-1} \mathrm{H}_{2} \mathrm{O}_{2}$ is distinct in the logarithmic stage from that in the post-logarithmic stage. While Torl and Tor2 show the upregulation in the post-logarithmic stage (Figure 7A), Torl exhibits the downregulation in the logarithmic stage (Figure 7B). In the logarithmic yeast, the expression levels of Snfl and Kss 1 induced by CR, $25 \mu \mathrm{mol}$ $\mathrm{L}^{-1}$ ART, or $20 \mu \mathrm{mol} \mathrm{L}{ }^{-1} \mathrm{H}_{2} \mathrm{O}_{2}$ are typically lower than those of NR, but they exhibit the expression alterations from low levels to high levels during logarithmic growth (Figure 7C and D).

\subsection{Covalent ART-COX conjugation functionally re- sembles reversible NO-COX interaction}

Until currently, no direct evidence confirms CR elicits ROS and induces antioxidant enzymes through triggering NO. Considering ART can alkylate the prosthetic heme moiety and hence inactivate heme-harboring proteins, we proposed ART may covalently conjugate to the hemoenzyme COX and inhibit its activity. In turn, inhibition of COX should induce Cox gene expression and finally increase COX ac- 

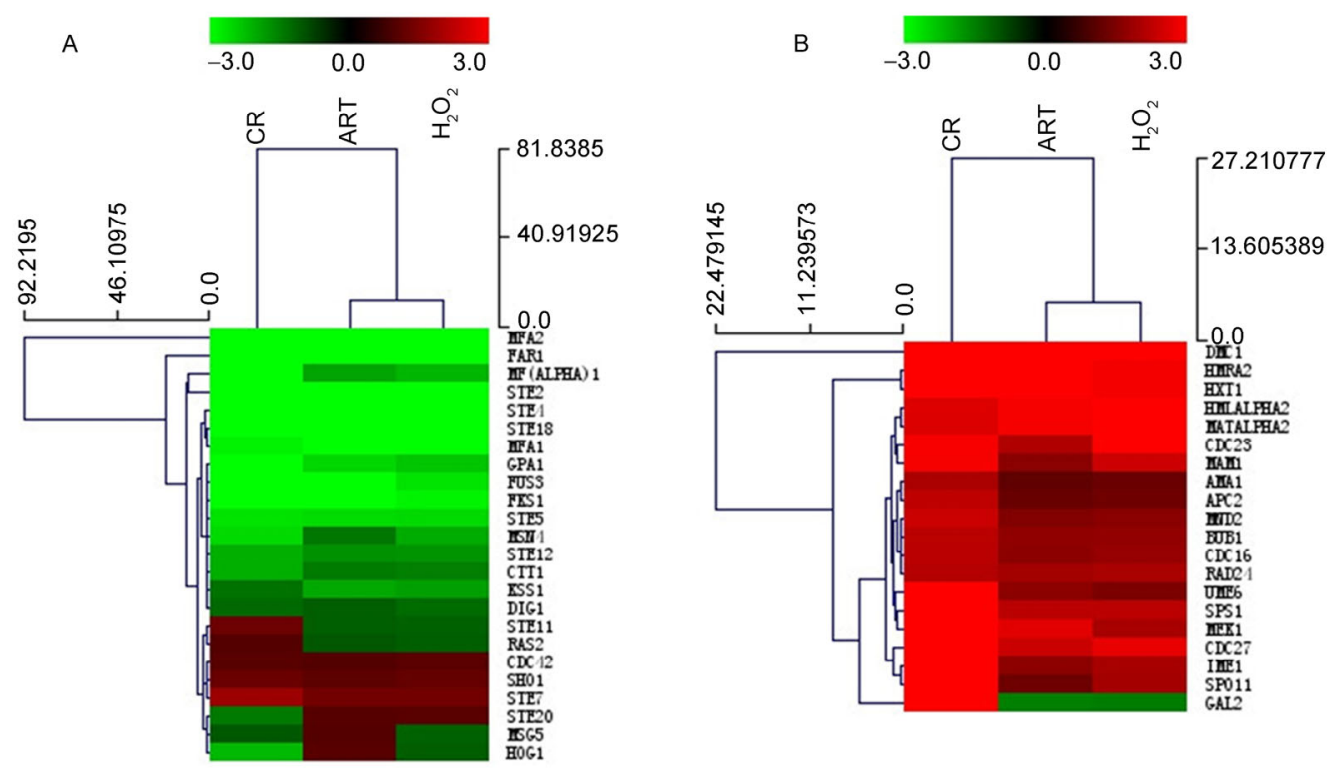

Figure 6 Up/downregulation of MAPK pathway genes and meiosis pathway genes in post-logarithmic yeast cells upon exposure to $\mathrm{CR}, \mathrm{ART}$, or $\mathrm{H}_{2} \mathrm{O}_{2}$. $\mathrm{A}$, MAPK pathway genes. B, Meiosis pathway genes. CR, $0.5 \%$ glucose; ART, $25 \mu \mathrm{mol} \mathrm{L}{ }^{-1} ; \mathrm{H}_{2} \mathrm{O}_{2}, 20 \mu \mathrm{mol} \mathrm{L}{ }^{-1}$.

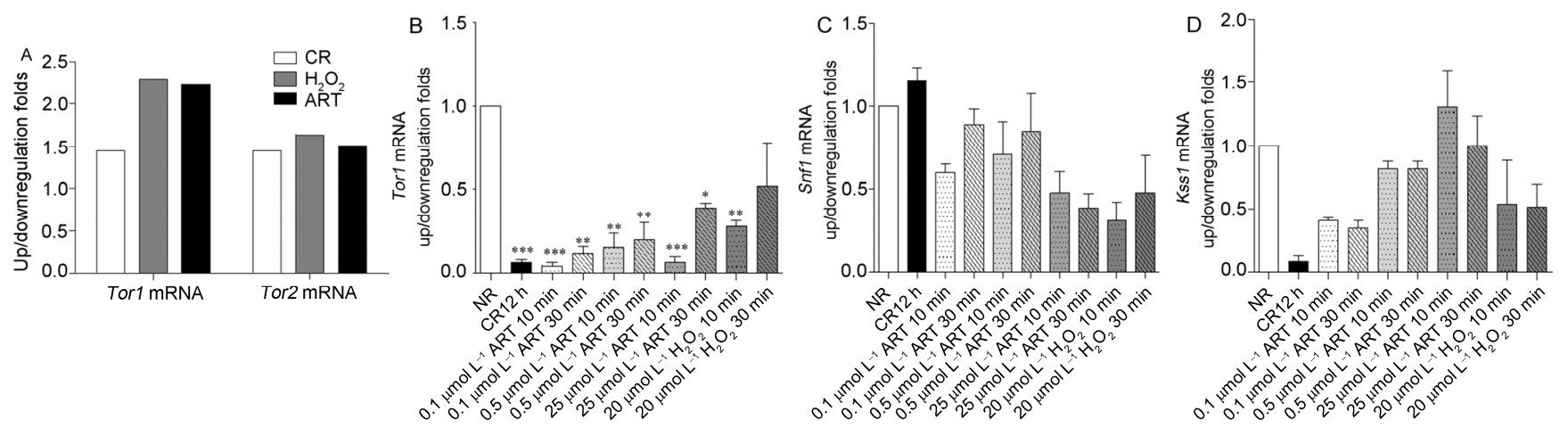

Figure 7 Up/downregulation of protein kinase genes in logarithmic or post-logarithmic yeast cells upon exposure to CR, ART, or $\mathrm{H}_{2} \mathrm{O}_{2}$. A, Torl and Tor2 expression levels in the post-logarithmic stage. B-D, Torl, Snf, and Kss1 expression levels in the logarithmic stage. NR, $2 \%$ glucose; CR, $0.5 \%$ glucose. *, $P<0.05 ; * *, P<0.01 ; * * *, P<0.001(n=3)$.
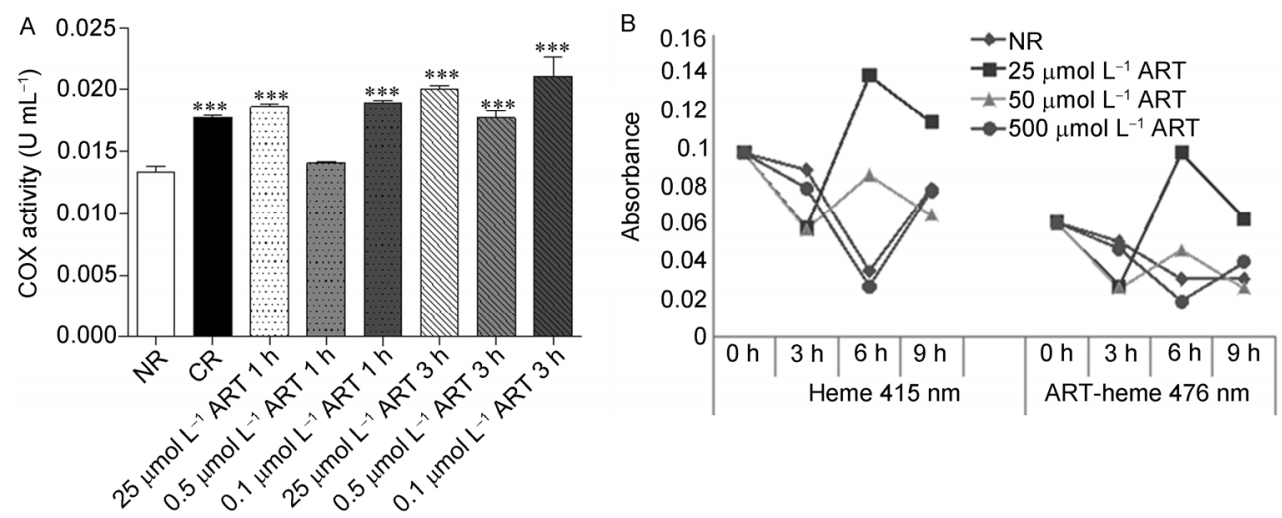

Figure 8 Correlation of ART-COX conjugation with COX induction and COX activity. A, ART- increased COX activity in different concentrations (0.1, 0.5 and $25 \mu \mathrm{mol} \mathrm{L}^{-1}$ ) and durations ( 1 and $3 \mathrm{~h}$ ). B. The ART-heme adduct detected after 3,6 and $9 \mathrm{~h}$ in 25,50 and $500 \mu$ mol L ${ }^{-1}$ ART-treated yeast. NR, $2 \%$ glucose; CR, $0.5 \%$ glucose. *, $P<0.05$; **, $P<0.01(n=3)$. 
tivity. Indeed, ART really increases yeast COX activity in different concentrations $\left(0.1,0.5\right.$ and $\left.25 \mu \mathrm{mol} \mathrm{L}{ }^{-1}\right)$ and after various durations ( 1 and $3 \mathrm{~h}$ ) (Figure $8 \mathrm{~A}$ ). This finding may interpret how ART modulates mitochondrial functions through simulation of the interaction of NO with COX by the conjugation of ART with COX.

As shown in Figure $8 \mathrm{~B}, A_{415}$ readings that represent heme and $A_{476}$ readings that represent ART-heme adduct increase after $3 \mathrm{~h}$ treatment by $25 \mu \mathrm{mol} \mathrm{L}{ }^{-1}$ ART, but both decrease after $3 \mathrm{~h}$ treatment by 50 or $500 \mu \mathrm{mol} \mathrm{L}^{-1}$ ART. For the group of $25 \mu \mathrm{mol} \mathrm{L}{ }^{-1}$ ART, the increase of heme may indicate de novo hemoprotein biosynthesis, and the increase of ART-heme adducts should validate ART-heme conjugation. In $50 \mu \mathrm{mol} \mathrm{L}{ }^{-1}$ and $500 \mu \mathrm{mol} \mathrm{L}{ }^{-1}$ ART groups, neither heme induction nor ART-heme conjugation were observed, implying an essential result of yeast cell death caused by the overdoses of ART.

Therefore, ART can functionally mimic CR-triggered NO to enhance ROS production and induce antioxidant responses, which may represent the consequence of compensatory enhancement of mitochondrial function. Accelerated ROS generation may be attributed to COX inhibition by ART, whereas reduced ROS emission can be the outcome of antioxidant induction upon mitochondrial enhancement.

\section{Discussion}

$\mathrm{CR}$ is convinced in delaying aging and prolonging lifespan among examined eukaryotes, either in the microbial yeast [6] or mammalian mice [7]. How can CR exert the beneficial effects on life expectancy remains debating, and some conclusions about CR-driven longevity are apparently controversial [24]. An implication of mitochondrial biogenesis in CR-extended lifespan has been suggested since last decade [7], but challenges to such explanatory notion has been lunched [16-18]. Mitochondrial biogenesis is characterized by enhanced respiratory activity, which means more glucose is consumed and much ATP produced for compensation of energy deficiency during CR exposure. However, this is an apparent paradoxical issue because glucose supply is extremely restricted in exposure to $\mathrm{CR}$.

As an urgent response to the suddenly occurring nutritional stress, a transient respiratory burst just at the start of glucose restriction should be possible because the unexpected insufficiency of ATP and NADH can be compensated by this emergent metabolic response. Nevertheless, $\mathrm{CR}$ was found to promote longevity in respiratory-deficient yeast strains [25], so respiratory burst is by no means a prerequisite for long life expectancy in yeast. To decipher the discrepancy regarding the correlation of mitochondrial biogenesis with lifespan extension, we introduced a novel concept of CR-based 'two-phase responses': a ME phase rep- resented by "acute CR" and a PME phase characterized by "chronic CR". In the former state, mitochondrial respiratory activity is enhanced, while in the latter state, mitochondrial respiratory activity attenuated.

To provide the experimental evidence supporting this proposition, we monitored the expression modes and activity dynamics of mitochondrial signatures including those for oxidative phosphorylation and antioxidation in the present investigation. Consequently, CR-induced overexpression of Cox1 and Sod2, and increased activities of COX and Mn-SOD were detected in ME yeast cells. In contrast, the downregulation of Coxl and $\operatorname{Sod} 2$ expression is followed by the decrease of COX and Mn-SOD activities in PME yeast cells. Therefore, CR-based dual-phase modes can be readily distinguished by the "up-and-down" mode of both mitochondrial signatures and antioxidant enzymes.

PME during chronic CR allows the downregulation of biosynthesis pathway genes and synchronous upregulation of degradation pathway genes. The alteration of gene expression patterns involves at least four kinds of major common metabolites: glucose, fatty acids, amino acids, and nucleotides. For those metabolites, while anabolism (biosynthesis) is decreased, catabolism (degradation) is accordingly increased. It has been concluded that yeast can respond robustly to decreasing glucose levels by shifting their metabolic state from one that favors fermentation to one that favors respiration [26]. It has also been proposed that a shift in carbon metabolism may account for the extension of CLS observed in response to CR [12].

Except for the upregulation of ubiquitylation genes responsible for selective protein degradation and amino acid recycle, we also found $\mathrm{CR}$ allows the overexpression of autophagy genes responsible for the reutilization of cellular constituents. It is known that yeast upregulates autophagy during entry into stationary phase, presumably as an adaptive response to the environmental stress [27]. Consistent with this notion, several yeast mutants defective for autophagy were found to have short-lived phenotypes in the CLS assay [28]. Besides, we also observed the upregulation of peroxisomal $\beta$-oxidation genes responsible for the oxidation of long-chain fatty acids. A most recently published report has indicated $\mathrm{CR}$-activated peroxisomal $\beta$-oxidation systems during yeast CLS contribute to energy regeneration by stored lipids and recycled cellular components [29].

It is believed that CR enables the decrease of ATP and $\mathrm{NADH}$, or the increase of AMP and $\mathrm{NAD}^{+}$, which can separately activate AMPK and SIRT1 [30,31]. In turn, AMPK and SIRT1 coordinately activate peroxisome proliferator-activated receptor $\gamma$ co-activator 1 alpha (PGC-1 $\alpha$ ) for mitochondrial biogenesis in mammals [32]. It has been reported that $\mathrm{NAD}^{+}$and Sir2 (yeast homolog of mammalian SIRT1) are required for yeast lifespan extension [33]. Also, co-activation of PGC-1 $\alpha$ (encoded by $P g c l$ in yeast) by AMPK (encoded by Snfl in yeast) and SIRT1 (encoded by 
Sir2 in yeast) leads to the initiation of transcription (mRNA biosynthesis) and translation (protein biosynthesis), probably occurring in the ME phase. However, no analytic data on the details of signal transduction during the PME phase are available. Because no significant fluctuations of Snfl and Sir2 were observed in PME yeast cells, we had to look for other candidate signal transducers. We noticed the marked downregulation of MAPK pathway genes among $\mathrm{CR}$, ART, and $\mathrm{H}_{2} \mathrm{O}_{2}$ groups. As indicated, Kssl/Fus3encoded yeast MAPK is closely related to mammalian ERK-type kinases, which functions as a critical checkpoint for protein biosynthesis [34,35]. In other words, if MAPK is inactivated, protein biosynthesis should be suppressed [36]. After exposure of PME yeast cells to CR, ART, or $\mathrm{H}_{2} \mathrm{O}_{2}$, downregulation of MAPK pathway genes and ribosomal protein genes occurs, implying protein biosynthesis is hampered in PME yeast cells. Similarly, it has also been reported that the inhibition of mRNA translation extends worm lifespan [37].

Why MAPK pathway genes were downregulated in PME yeast cells following treatment by $\mathrm{CR}, \mathrm{ART}$, or $\mathrm{H}_{2} \mathrm{O}_{2}$ ? To answer this question, it should be mentioned that ROS is almost thoroughly scavenged due to potent antioxidative responses provoked by CR, ART, or $\mathrm{H}_{2} \mathrm{O}_{2}$. During this process, Sod1 and Sod 2 are induced in ME yeast cells, whereas Cta2 and Gpxl are otherwise induced in PME yeast cells. Also, it is noteworthy that ROS is a powerful activator of all MAPK subfamilies (ERK, JNKs and p38-MAPK) [38]. Indeed, we did not observe the upregulation of Sod1, Sod2, and other antioxidant genes that generate $\mathrm{H}_{2} \mathrm{O}_{2}$ except for Cta2 and Gpxl that degrade $\mathrm{H}_{2} \mathrm{O}_{2}$ in PME yeast cells, suggesting an extremely low ROS level due to an active antioxidative response. Therefore, it seems that MAPK may not be activated due to ROS deprival although the correlation of ROS levels with MAPK activity and MAPK gene expression is yet to be identified in yeast. On the other hand, it is accepted that protein kinases are implicated in yeast longevity $[19,29,39,40]$, we actually observed the significant upregulation of Torl in PME yeast cells, which is as same as the case described in fission yeast [41]. It is unclear, however, whether the upregulation of Torl is due to the inhibition of Torlp per se upon exposure of yeast cells to CR, ART, or $\mathrm{H}_{2} \mathrm{O}_{2}$.

Numerous investigations on CR paradigms have revealed markedly elevated NO levels although NOS homologues have not been found in yeast [12]. However, COX was proposed to produce NO from nitrite under hypoxic conditions $[13,42]$. We really detected potent NO burst during $\mathrm{CR}$, but no elevation of NO levels was detected when the NOS substrate L-arginine was added in yeast cultures (data not shown). On the other hand, it has been shown that the mitochondrial uncoupler dinitrophenol (DNP) significantly increases the expression of mitochondrial biomarkers, PGC-1a, COX and mitofusin-2, indicating DNP-mediated mitochondrial uncoupling promotes mitochondrial biogenesis [43]. Our results describing the inducible expression of Coxl in yeast cells following exposure to ART seem to support the preposition that NO-COX interaction can be mimicked by ART-COX conjugation. The covalent binding of ART to COX has been monitored by a time-course assay of the ART-heme adduct, along with the synchronous measurement of increased COX activity.

A correlation of enhanced respiration by potent antioxidation as one of the mechanisms of longevity has been established in yeast, worm and mice, among which a growing body of literature has indicated mitochondrial ROS can act as the mediators of adaptive/hormetic effects on yeast life span [44-46]. A recent study has also shown CR elevates $\mathrm{H}_{2} \mathrm{O}_{2}$ levels in an early stationary phase, and induces SOD activity to help extending CLS [20,47]. Our results showing $\mathrm{H}_{2} \mathrm{O}_{2}$ can mimic CR to extend yeast CLS provides supports to such putative mechanisms. Another supporting evidence comes from a recent work indicating a mitochondrial superoxide signal triggers increased longevity in worm [48]. Although the detailed mechanism underlying $\mathrm{H}_{2} \mathrm{O}_{2-}$ mediated lifespan extension remains inclusive, it is most likely related to the induction of antioxidant enzymes and repression of MAPK signaling, as mentioned above.

It is found that, in the present investigation, CR-exposed yeast cells exhibit no remarkable induction of $\operatorname{Sod} 2$ genes but significant activation of Sod2-encoded Mn-SOD. Our previous work has also indicated ART can significantly increase the activity of Mn-SOD [49]. In this aspect, a recent report provides a possible explanation: activation of Mn-SOD needs SIRT3 for the de-acetylation of two critical lysine residues [50], suggesting CR may modulate Mn-SOD activity post-translationally rather than transcriptionally. Additionally, ART mimics CR seemly in fully different ways from the previously described CR mimics. While ART behaves like mitochondrial uncouplers such as DNP [43], rapamycin acts as an inhibitor of mTORC1 [51], and resveratrol serves as an activator of SIRT1 [52] or as an inhibitor of cAMP phosphodiesterases [53].

Figure 9 schematically illustrates the proposed model representing ART-driven yeast lifespan extension by the modes of dual-phase responses. In the ME phase, mRNA and protein synthesis increases, and respiration is enhanced by accelerated mitochondrial biogenesis. In the PME phase, mRNA and protein synthesis decreases, and respiration is decayed by suppressed mitochondrial biogenesis.

Recently, we have established a perfect relationship between enhanced antioxidative responses and compromised telomere shortening via downregulation of the tumor suppressor BRCA1 in mice, so our future work on CRextended yeast lifespan is further elucidation on a possible correlation of attenuated oxidative DNA damage and compromised telomere shortening with prolonged life expectancy in yeast cells. 


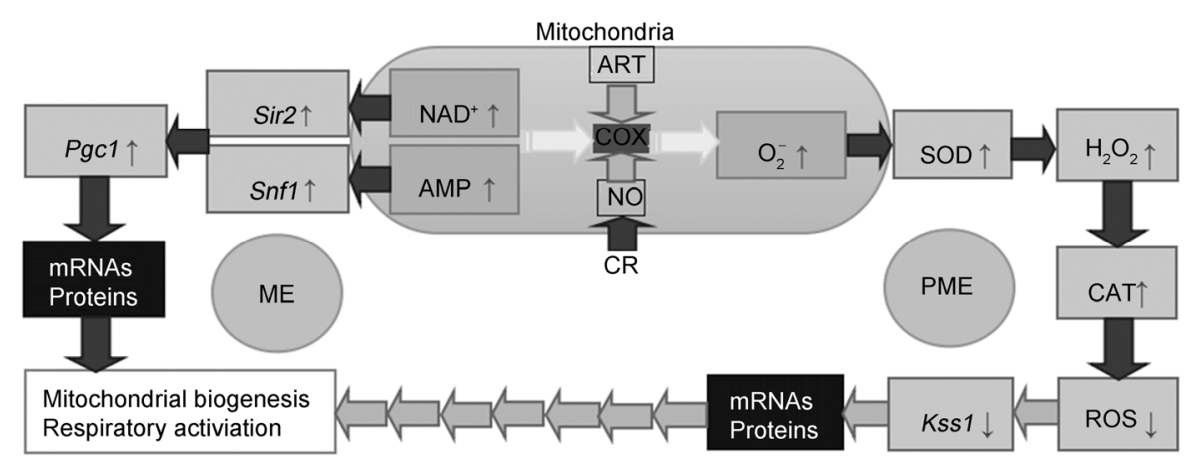

Figure 9 A putative signaling pathway responsible for yeast lifespan extension involved in the mode of dual-phase responses. The black arrows indicate a promotion role (positive control), the gray arrows indicate a repression role (negative control), and the white arrows represent the direction of electron transport along the mitochondrial respiratory chain. The up arrow $(\uparrow)$ within a frame shows an elevation level, and the down arrow $(\downarrow)$ within a frame shows a decline level. AMP, adenosine monophosphate; ART, artesunate; CAT, catalase; COX, cytochrome $c$ oxidase; CR, calorie restriction; ME, mitochondrial enhancement; $\mathrm{NAD}^{+}$, oxidized nicotinamide dinucleotide; NO, nitric oxide; PME, post-mitochondrial enhancement; ROS, reactive oxygen species; SOD, superoxide dismutase.

\section{Conclusion}

CR exerts a role in yeast CLS extension through two mechanisms: the one is an enhanced antioxidation to mitigate ROS generation in the ME phase via respiratory burst; and another is an attenuated metabolism to deal with food shortage in the PME phase via respiratory decay. CR-extended CLS can be partially mimicked by ART and $\mathrm{H}_{2} \mathrm{O}_{2}$ via the induction of antioxidant responses and the promotion of metabolic alterations, which has been mirrored by global transcriptome profiling and other sensitive detection procedures.

The authors declare that they have no conflict of interest.

We thank Kang Chen Biotech Co. Ltd. for carrying out microarray service. This work was supported by grants to Zeng QingPing from National Natural Science Foundation of China (81273620).

1 Koubova J, Guarente L. How does calorie restriction work? Genes Dev, 2005, 17: 313-321

2 Jiang JC, Jaruga E, Repnevskaya MV, Jazwinski SM. An intervention resembling calorie restriction prolongs life span and retard aging in yeast. FASEB J, 2000, 14: 2135-2137

3 Walker G, Houthoofd K, Vanfleteren JR, Gems D. Dietary restriction in C. elegans: from rate-of-living effects to nutrient sensing pathways. Mech Age Dev, 2005, 126: 929-937

4 Rogina B, Helfand S L. Sir2 mediates longevity in the fly through a pathway related to calorie restriction. Proc Natl Acad Sci USA, 2004, 101: 15998-16003

5 Youngman LD, Park JY, Ames BN. Protein oxidation associated with aging is reduced by dietary restriction of protein or calories. Proc Natl Acad Sci USA, 1992, 89: 9112-9116

6 Skinner C, Lin SJ. Effects of calorie restriction on life span of microorganisms. Appl Microbiol Biotechnol, 2010, 88: 817-828

7 Nisoli E, Clementi E, Paolucci C, Xozzi V, Tonello C, Sciorati C, Bracale R, Valerio A, Francolini M, Moncada S, Carruba MO. Mitochondrial biogenesis in mammals: the role of endogenous nitric oxide. Science, 2003, 299: 896-899
8 Nisoli E, Falcone S, Tonello C, Cozzi V, Palomba L, Fiorani M, Pisconti A, Brunelli S, Cardile A, Francolini M, Cantoni O, Carruba MO, Moncada S, Clementi E. Mitochondrial biogenesis by NO yields functionally active mitochondria in mammals. Proc Natl Acad Sci USA, 2004, 101: 16507-16512

9 Nisoli E, Carruba MO. Nitric oxide and mitochondrial biogenesis. J Cell Sci, 2006, 119: 2855-2862

10 Li B, Skinner C, Castello PR, Kato M, Easlon E, Xie L, Li T, Lu SP, Wang C, Tsang F, Poyton RO, Lin SJ. Identification of potential calorie restriction-mimicking yeast mutants with increased mitochondrial respiratory chain and nitric oxide levels. J Aging Res, 2011, 2011: 673185

11 Lewinska A, Macierzynska E, Grzelak A, Bartosz G. A genetic analysis of nitric oxide-mediated signaling during chronological aging in the yeast. Biogerontology, 2011, 12: 309-320

12 Kig C, Temizkan G. Nitric oxide as a signaling molecule in the fission yeast Schizosaccharomyces pombe. Protoplasma, 2009, 238: 59-66

13 Castello PR, David PS, McClure T, Crook Z, Poyton RO. Mitochondrial cytochrome oxidase produces nitric oxide under hypoxic conditions: implications for oxygen sensing and hypoxic signaling in eukaryotes. Cell Metab, 2006, 3: 277-287

14 Lin SJ, Kaeberlein M, Andalis AA, Sturtz LA, Defossez PA, Culotta VC, Fink GR, Guarente L. Calorie restriction extends Saccharomyces cerevisiae lifespan by increasing respiration. Nature, 2002, 418: 344-348

15 Civitarese AE, Carling S, Heilbronn LK, Hulver MH, Ukropcova B, Deutsch WA, Smith SR, Ravussin E, CALERIE Pennington Team. Calorie restriction increases muscle mitochondrial biogenesis in healthy humans. PLoS Med, 2007, 4: e76

16 Lanza IR, Zabielski P, Klaus KA, Morse DM, Heppelmann CJ, Bergen HR 3rd, Dasari S, Walrand S, Short KR, Johnson ML, Robinson MM, Schimke JM, Jakaitis DR, Asmann YW, Sun Z, Nair KS. Chronic caloric restriction preserves mitochondrial function in senescence without increasing mitochondrial biogenesis. Cell Metab, 2012, 16: 777-788

17 Hancock CR, Han DH, Higashida K, Kim SH, Holloszy JO. Does calorie restriction induce mitochondrial biogenesis? A reevaluation. FASEB J, 2011, 25: 785-791

18 Miller BF, Robinson MM, Bruss MD, Hellerstein M, Hamilton KL. A comprehensive assessment of mitochondrial protein synthesis and cellular proliferation with age and caloric restriction. Aging Cell, 2012, 11: 150-161

19 Pan Y, Schroeder EA, Ocampo A, Barrientos A, Shadel GS. Regulation of yeast chronological life span by TORC1 via adaptive mito- 
chondrial ROS signaling. Cell Metab, 2011, 13: 668-678

20 Mesquita A, Weinberger M, Silva A, Sampaio-Marques B, Almeida B, Leao C, Costa V, Rodrigues F, Burthans WC, Ludovico P. Caloric restriction or catalase inactivation extends yeast chronological lifespan by inducing $\mathrm{H}_{2} \mathrm{O}_{2}$ and superoxide dismutase activity. Proc Natl Acad Sci USA, 2010, 107: 15123-15128

21 Mason M, Nicholes GP, Wilson MT, Cooper CE. Nitric oxide inhibition of respiration involves both competitive (heme) and noncompetitive (copper) binding to cytochrome c oxidase. Proc Natl Acad Sci USA, 2006, 103: 708-713

22 Zhang SM, Gerhard GS. Heme mediates cytotoxicity from artemisinin and serves as a general anti-proliferation target. PLoS One, 2009, 4: e7472

23 Zeng QP, Xiao N, Wu P, Yang XQ, Zeng LX, Guo XX, Zhang PZ, Qiu F. Artesunate potentiates antibiotics by inactivating bacterial heme-harbouring nitric oxide synthase and catalase. BMC Res Notes, 2011, 4: 223

24 Piper MDW, Partridge L, Raubenheimer D, Simpson SJ. Dietary restriction and aging: a unifying perspective. Cell Metab, 2011, 14: $154-160$

25 Kaeberlein M, Hu D, Kerr EO, Tsuchiya M, Westman EA, Dang N, Fields S, Kennedy BK. Increased lifespan due to calorie restriction in respiratory deficient yeast. PLoS Genet, 2005, 1: e69

26 Kaeberlein M, Burtner CR, Kennedy BK. Recent developments in yeast aging. PLoS Genet, 2007, 3: e84

27 Kamada Y, Sekito T, Ohsumi Y. Autophagy in yeast: a TOR-mediated response to nutrient starvation. Curr Top Microbiol Immunol, 2004, 279: 73-84

28 Powers RW 3rd, Kaeberlein M, Caldwell SD, Kennedy BK, Fields S. Expression of chronological life span in yeast by decreased TOR pathway signaling. Genes Dev, 2006, 20: 171-184

29 Lefevre SD, van Roermund CW, Wanders RJ, Veenhuis M, van der Klei IJ. The significance of peroxisome function in chronological aging of Saccharomyces cerevisiae. Aging Cell, 2013, 12: 784-793

30 Rodgers JT, Lerin C, Haas W, Gygi SP, Spiegelman BM, Puigserver P. Nutrient control of glucose homeostasis through a complex of PGC-1 alpha and SIRT1. Nature, 2005, 434: 113-118

31 Canto C, Gerhart-Hines Z, Feige JN, Lagouge M, Noriega L, Milne JC, Elliott PJ, Puigserver P, Auwerx J. AMPK regulates energy expenditure by modulating NAD metabolism and SIRT1 activity. Nature, 2009, 458: 1056-1060

32 Lee WJ, Kim M, Park HS, Kim HS, Jeon MJ, Oh KS, Koh EH, Won JC, Kim MS, Oh GT, Yoon M, Lee KU, Park JY. AMPK activation increases fatty acid oxidation in skeletal muscle by activating PPAR alpha and PGC-1. Biochem Biophys Res Commun, 2006, 340: 291-295

33 Lin SJ, Defossez PA, Guarente L. Requirement of NAD and SIR2 for life-span extension by calorie restriction in Saccharomyces cerevisiae. Science, 2000, 289: 2126-2128

34 Gustin MC, Albertyn J, Alexander M, Davenport K. MAP kinase pathways in the yeast Saccharomyces cerevisiae. Microbiol Mol Biol Rev, 1998, 62: 1264-1300

35 Pearson G, Robinson F, Beers Gibson T, Xu BE, Karandikar M, Berman K, Cobb MH. Mitogen-activated protein (MAP) kinase pathways: regulation and physiological functions. Endocr Rev, 2001, 22: $153-183$

36 Son Y, Cheong YK, Kim NH, Chung HT, Kang DG, Pae HO. Mitogen-activated protein kinases and reactive oxygen species: how can ROS activate MAPK pathways? J Signal Transduct, 2011, 2011: 792639
37 Pan KZ, Palter JE, Rogers AN, Olsen A, Chen D, Lithgow GJ, Kapahi P. Inhibition of mRNA translation extends lifespan in Caenorhabditis elegans. Aging Cell, 2007, 6: 111-119

38 Gaitanaki C, Konstantina S, Chrysaand S, Beis I. Oxidative stress stimulates multiple MAPK signalling pathways and phosphorylation of the small HSP27 in the perfused amphibian heart. J Exp Biol, 2003, 206: 2759-2769

39 Fabrizio P, Pozza SD, Pletcher CM, Longo VD. Regulation of longevity and stress resistance by Sch9 in yeast. Science, 2001, 292: 288-290

40 Thomson DM, Fick CA, Gordon SE. AMPK activation attenuates S6K1, 4E-BP1, and eEF2 signaling responses to high-frequency electrically stimulated skeletal muscle contractions. J. Appl Physiol, 2008, 104: 625-632

41 Rollis C, Codlin S, Bähler J. TORC1 signaling inhibition by rapamycin and caffeine affect lifespan, global gene expression, and cell proliferation of fission yeast. Aging Cell, 2013, 12: 563-573

42 Taylor CT, Moncada S. Nitric oxide, cytochrome c oxidase, and the cellular response to hypoxia, arteriosclerosis, thrombosis. Vascul Biol, 2010, 30: 643-647

43 Cerqueira FM, Laurindo FRM, Kowaltowski AJ. Mild mitochondrial uncoupling and calorie restriction increase fasting eNOS, Akt and mitochondrial biogenesis. PLoS One, 2011, 6: e18433

44 Agarwal S, Sharma S, Agarwal V, Roy N. Calorie restriction augments ROS defense in S. cerevisiae, by a Sir2p independent mechanism. Free Radic Res, 2005, 39: 55-62

45 Kharade SV, Mittal N, Das SP, Sinha P, Poy N. Mrg19 depletion increase $S$. cerevisiae lifespan by augmenting ROS defence. FEBS Lett, 2005, 579: 6809-6813

46 Piper PW, Harris NL, MacLean M. Preadaptation to efficient respiratory maintenance is essential both for maximal longevity and the retention of replicative potential in chronological ageing yeast. Mech. Ageing Dev, 2006, 127: 733-740

47 Schulz TJ, Zarse K, Voigt A, Urban N, Birringer M, Ristow M. Glucose restriction extends Caenorhabditis elegans life span by inducing mitochondrial respiration and increasing oxidative stress. Cell Metab, 2007, 6: 280-293

48 Yang W, Hekimi S. A mitochondrial superoxide signal triggers increased longevity in Caenorhabditis elegans. PLoS Biol, 2010, 8: e 1000556

49 Wang DT, Zeng QP. Hormesis mimics calorie restriction to extend yeast lifespan by modulation of transporter gene expression profiles and lipid metabolism modes. Microbiol China, 2014, 41: 1-10

50 Qiu X, Brown K, Hirschey MD, Verdin E, Chen D. Calorie restriction reduces oxidative stress by SIRT3-mediated SOD2 activation. Cell Metab, 2010, 12: 662-667

51 Harrison DE, Strong R, Sharp ZD, Nelson JF, Astle CM, Flurkey K, Nadon NL, Wilkinson JE, Frenkel K, Carter CS, Pahor M, Javors MA, Fernandez E, Miller RA. Rapamycin fed late in life extends lifespan in genetically heterogeneous mice. Nature, 2009, 460: 392-395

52 Borra MT, Smith BC, Denu JM. Mechanism of human SIRT1 activation by resveratrol. J Biol Chem, 2005, 280: 17187-17195

53 Park SJ, Ahmad F, Philp A, Baar K, Williams T, Luo H, Ke H, Rehmann H, Taussig R, Brown AL, Kim MK, Beaven MA, Burgin $\mathrm{AB}$, Manganiello V, Chung JH. Resveratrol ameliorates aging-related metabolic phenotypes by inhibiting cAMP phosphodiesterases. Cell, 2012, 148: 421-433

Open Access This article is distributed under the terms of the Creative Commons Attribution License which permits any use, distribution, and reproduction in any medium, provided the original author(s) and source are credited. 


\section{Supporting Information}

Figure S1 An overview of transcriptome-wide profiling in yeast after the CR, ART, or $\mathrm{H}_{2} \mathrm{O}_{2}$ treatment.

Figure S2 Gene ontology diagrams for most enriched categories of KEGG pathways within the CR, ART, or $\mathrm{H}_{2} \mathrm{O}_{2}$ group.

The supporting information is available online at life.scichina.com and link.springer.com. The supporting materials are published as submitted, without typesetting or editing. The responsibility for scientific accuracy and content remains entirely with the authors. 